\title{
Axial Load-carrying Capacity of Steel Tubed Concrete Short Columns Confined with Advanced FRP Composites
}

\author{
Ali Raza1', Syyed Adnan Raheel Shah", Mudasser Muneer Khan², Faraz ul Haq ${ }^{1}$, Hunain Arshad ${ }^{1}$, \\ Muhammad Farhan', Muhammad Waseem³
}

\footnotetext{
1 Department of Civil Engineering, Pakistan Institute of Engineering and Technology, Multan, 66000, Pakistan

2 Department of Civil Engineering, Bahauddin Zakariya University, Multan, 66000, Pakistan

${ }^{3}$ Bayreuth Centre for Ecology and Environmental Research, University of Bayreuth, 95440 Bayreuth, Germany

* Corresponding author, e-mail: syyed.adnanraheelshah@uhasselt.be
}

Received: 29 October 2019, Accepted: 02 May 2020, Published online: 02 June 2020

\begin{abstract}
Fiber Reinforced Polymers (FRPs) have wide applications in the field of concrete construction due to their superior performance over conventional materials. This research focuses on the structural behavior of steel tube FRP jacket-confined concrete (STFC) columns under axial concentric loading and proposes a new empirical equation for predicting the axial load-carrying capacity of STFC columns having thickness of FRP-fabric ranging from $0.09 \mathrm{~mm}$ to $5.9 \mathrm{~mm}$. A large database of 700 FRP-confined concrete specimens is developed with the detailed information of critical parameters, i.e. elastic modulus of FRPs $\left(E_{f}\right)$, compressive strength of unconfined concrete $\left(f_{c 0}^{\prime}\right)$, diameter of specimen $(D)$, height of specimen $(H)$, total thickness of FRPs $\left(N . t_{f}\right)$, and the ultimate strength of confined concrete $\left(f_{c c}^{\prime}\right)$. After the preliminary evaluation of constructed database, a new empirical model is proposed for the prediction of axial compressive strength of FRP-confined specimens using general regression analysis by minimizing the error functions such as root mean squared error (RMSE) and coefficient of determination $\left(R^{2}\right)$. The proposed FRP-confinement strength model presented higher accuracy as compared with previously proposed models. Finally, an equation is proposed for the predictions of axial load carrying capacity of STFC columns. For the validation of proposed equation, an extensive parametric study is performed using the proposed nonlinear finite element model (FEM). The FEM is calibrated using the load-deflection results of STFC columns from literature. A close agreement was observed between the predictions of proposed finite element model and proposed capacity equation.
\end{abstract}

\section{Keywords}

FRPs, axial capacity, confined concrete, concrete damaged plastic (CDP) model, finite elements model (FEM), parametric

\section{Introduction}

Due to the superior properties of advanced fiber-reinforced polymers (FRPs) such as high tensile strength, corrosion resistance, tailored aesthetic look, low thermal and electrical conductance, high resistance to chemicals attack, long-term durability and dimensional stability in comparison with steel, their use as external wraps to enhance the axial strengths of structural members when the internal reinforcement is insufficient, is being used worldwide. FRP jacketing is also advantageous on conventional steel and concrete jacketing due to many factors such as easy handling, easy installation, slight disturbance of structure and less time consumption [1]. Stainless steel has favorable mechanical properties to be used in the structures as a competitive material [2]. Although the steel tube confinement effectively enhances the concrete strength but, the outward local buckling of the column will decrease the effectiveness of steel tube confinement resulting in the degradation of axial load carrying capacity and ductility of columns [3, 4]. Thus, the additional confinement provided by the FRP will be useful for the prevention of outward local buckling [5]. FRP is also used in buildings and bridges due to damages in earthquake for the rehabilitation and retrofitting for enhancement of the strength [6-14].

A large number of studies were found in the literature that investigates the structural performance of conventional and stainless steel-tube concrete compression members with and without FRP confinements [15-23]. From these studies, it was observed that the confinements increase the strength and strain ductility of the composite concrete compression members. The structural behavior of 
the laminated composite concrete structures was superior to either concrete or steel structures because the concrete and confining material give a combined action where the FRP and/or steel tube plays an important role in confining the concrete core material and the concrete core material prevents the local buckling phenomenon. It is considered that the empirical models proposed using regression analysis do not predict well the behavior of FRP confined concrete because of the reason that the behavior of FRPconfined concrete depends upon many variables having a complex relationship with each other for a noisy experimental data. To overwhelm this problem, a large database is required by minimizing the noisiness of data so that the proposed model for axial capacity of confined concrete members should be more accurate. Recently, various new empirical models for ultimate conditions of steel tube and/or FRP-confined concrete members have been proposed [24-34] based on the genetic programming, regression analysis, and neural networks.

Fardis and Khalili [35] studied the FRP confined concrete and presented a strength model for the FRP confined specimens after examining the models given by Richart et al. [36] and Newman and Newman [37]. These models were proposed with limited mechanical and geometric variables which is the weakness of these models causing no guarantee for further applicability. By increasing the data points of experimental work and validation of the proposed models by other means such as self-supported experimental work and verification by nonlinear finite element analysis can lead the models to greater accuracy. Mander et al. [38] proposed new models for the ultimate strength and strain of internal transverse confinement of concrete. The models proposed by Lam and Teng [39] were used by ACI 440.2R-08 design guidelines with some minor alterations. The rupture strain of hoop fibers was not taken into consideration in the models for confined concrete proposed in the 90's and the ultimate tensile strain of FRPs given by the manufacturer was used but the recent research show that the FRPs are ruptured at usually lower strain as compared with actual fiber strains [39-41].

Extensive FEA simulations have been performed in the previous research to examine the structural behavior of either concrete-filled steel tubular columns (CFST) or FRP-confined concrete columns [42-51]. However, none of the researchers developed the FEA model for analyzing the structural behavior of steel-tube FRP confined concrete composite columns. Patel et al. [52] proposed a fiber element model based on the experimental study for the structural performance of circular concrete-filled stainless-steel tubular (CFSST) columns which predicted the numerical and experimental ultimate loads accurately. Moreover, they concluded that Eurocode 4 and ACI 318 underestimate the axial capacity of CFSST columns significantly. Tao et al. [53] proposed a non-linear FEA model of concrete-filled square stainless steel stub columns using ABAQUS. The FEA prediction in terms of axial load-axial deflection curves and ultimate axial capacity were in a close agreement with the experimental results. Furthermore, by using numerical simulations, the structural performance of carbon steel composite columns was compared with that of concrete-filled square stainless-steel stub columns. Ellobody et al. [54] and Hassanein et al. [43] performed FEA studies on the performance of CFSST columns under concentric loading. The finite element models given by these researchers accurately predicted the structural performance of CFSST columns by taking in to account the influence of strain hardening and confinement mechanisms of steel tube.

\subsection{Scope and significance}

Most of the existing axial strength models for the FRPconfined specimens were developed using the small number of experimental databases and curve-fitting techniques with limited curve fitting functions in which researchers cannot cover all the interrelations and combinations of the variables to access an accurate model. Therefore, further research with wider range of experimental data adopting the more rigorous approach is needed to propose a more general empirical model. In the present study, general regression analysis was implemented for the prediction of axial compressive strength of FRP-confined concrete using a large database of 700 concrete specimens externally confined with FRPs from different researches. Finally, a relationship for axial load-carrying capacity of STFC columns was proposed. The proposed model in the present study was validated against the predictions of FEA model using ABAQUS. The numerical results of ABAQUS were validated against the experiments of STFC columns from Liu et al. [22] by comparing the FEA predictions with the experimental axial load-deflection behavior. The proposed empirical equation can accurately predict the load-carrying capacity of STFC columns which is helpful for the analysis and design of confined concrete structural members. 


\section{Confinement mechanism of FRP}

The existing empirical strength models contain some common parameters such as confinement stiffness ratio $\left(\rho_{k}\right)$, the maximum confinement stress due to FRP jacket $\left(f_{l}\right)$, strain ratio $\left(\rho_{\varepsilon}\right)$ and hoop rupture strain of FRP jacket $\left(\varepsilon_{h, \text { rup }}\right)$. The relationships for $\rho_{k}$ and $\rho_{\varepsilon}$ were presented by Teng et al. [55] as given by Eq. (1) and Eq. (2).

$$
\begin{aligned}
& \rho_{\varepsilon}=\frac{\varepsilon_{h, \text { rup }}}{\varepsilon_{c o}}, \\
& \rho_{k}=\frac{2 E_{f} t_{f}}{\left(\frac{f_{c o}^{\prime}}{\varepsilon_{c o}}\right) D},
\end{aligned}
$$

where $E_{f}$ is Young's modulus of confinement sheets in the transverse direction of specimens, $t_{f}$ is the thickness of FRP jacket, $f_{c o}^{\prime}$ is the compressive strength of unconfined concrete and $\varepsilon_{c o}$ is the axial strain of unconfined concrete. Fig. 1 shows the mechanics of confinement of the FRPjackets having a hoop diameter $\mathrm{D}$.

The relation for maximum confinement stress based on Fig. 1 can be written as follows:

$f_{l}=\rho_{\varepsilon} \rho_{k} f_{c o}^{\prime}=\frac{2 E_{f} \varepsilon_{h, r u p} N t_{f}}{D-2 t_{s}}$,

where, $N$ is the number of FRP wraps. A mathematical expression (Eq. 4) for the hoop rupture strain of confinement was established by Lim et al. [56] using the genetic programming formulation process which was used for the specimens whose hoop rupture strain was unknown.

$\varepsilon_{h, \text { rup }}=\frac{\varepsilon_{f}}{f_{c o}^{\prime 0.125}}$,

where, $\varepsilon_{f}$ is the maximum tensile strain of fibres. Some of the strength models proposed in the previous researches for the confinement effects of FRP confined specimens

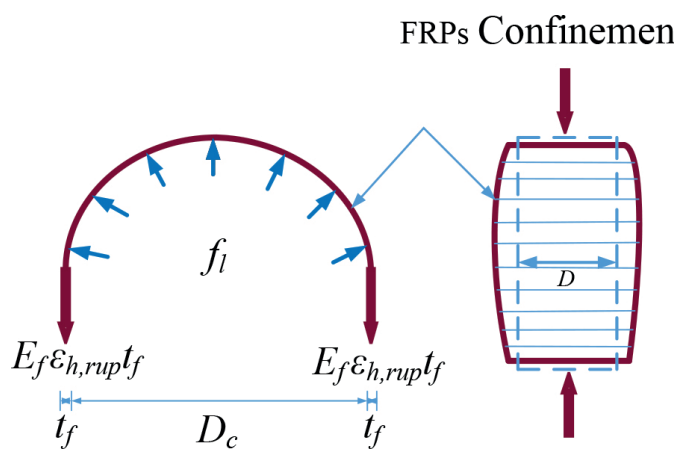

Fig. 1 Confinement mechanics of FRP sheets have been presented in Table 1. The selected models have wide applications in the literature due to their easiness in applications.

\section{Constructed database}

In the present study, a large database of 700 confined concrete cylindrical specimens is formed from the previous experimental works. The diameter of specimens varies from $51 \mathrm{~mm}$ to $406 \mathrm{~mm}$ having an average value of $152 \mathrm{~mm}$, the compressive strength of unconfined concrete varies from 12.4 MPa to $188.2 \mathrm{MPa}, 497$ specimens were confined with carbon fiber reinforced polymer (CFRP) wraps, 143 specimen were confined with glass FRP wraps, 27 specimens were confined with aramid FRP wraps, and

\begin{tabular}{|c|c|}
\hline Model & Expression for strength of FRP confined concrete \\
\hline $\begin{array}{l}\text { Fardis and } \\
\text { Khalili [35] } \\
\text { model }\end{array}$ & $\frac{f_{c c}^{\prime}}{f_{c o}^{\prime}}=1+3.7\left(\frac{f_{l}}{f_{c o}^{\prime}}\right)^{0.86}$ \\
\hline $\begin{array}{l}\text { Richart et al. } \\
\text { [36] model }\end{array}$ & $\frac{f_{c c}^{\prime}}{f_{c o}^{\prime}}=1+4.1 \frac{f_{l}}{f_{c o}^{\prime}}$ \\
\hline $\begin{array}{l}\text { Newman and } \\
\text { Newman [37] } \\
\text { model }\end{array}$ & $\frac{f_{c c}^{\prime}}{f_{c o}^{\prime}}=1+3.7\left(\frac{f_{l}}{f_{c o}^{\prime}}\right)^{2}$ \\
\hline $\begin{array}{l}\text { Mander et al. } \\
\text { [38] model }\end{array}$ & $\frac{f_{c c}^{\prime}}{f_{c o}^{\prime}}=2.254 \sqrt{1+7.94 \frac{f_{l}}{f_{c o}^{\prime}}}-2 \frac{f_{l}}{f_{c o}^{\prime}}-1.254$ \\
\hline $\begin{array}{l}\text { Lam and Teng } \\
\text { [39] model }\end{array}$ & $\frac{f_{c c}^{\prime}}{f_{c o}^{\prime}}=1+3.3 \frac{f_{l}}{f_{c o}^{\prime}}$ \\
\hline $\begin{array}{l}\text { Teng et al. [55] } \\
\text { model }\end{array}$ & $\frac{f_{c c}^{\prime}}{f_{c o}^{\prime}}=1+3.5\left(\rho_{k}-0.01\right) \rho_{\varepsilon}$ \\
\hline $\begin{array}{c}\text { Karbhari and } \\
\text { Gao [57] model }\end{array}$ & $\frac{f_{c c}^{\prime}}{f_{c o}^{\prime}}=1+2.1\left(\frac{f_{l}}{f_{c o}^{\prime}}\right)^{0.87}$ \\
\hline $\begin{array}{l}\text { Saafi et al. [58] } \\
\text { model }\end{array}$ & $\frac{f_{c c}^{\prime}}{f_{c o}^{\prime}}=1+2.2\left(\frac{f_{l}}{f_{c o}^{\prime}}\right)^{0.84}$ \\
\hline $\begin{array}{l}\text { Matthys et al. } \\
\text { [59] model }\end{array}$ & $\frac{f_{c c}^{\prime}}{f_{c o}^{\prime}}=1+2.3\left(\frac{f_{l}}{f_{c o}^{\prime}}\right)^{0.85}$ \\
\hline $\begin{array}{c}\text { Toutanji [60] } \\
\text { model }\end{array}$ & $\frac{f_{c c}^{\prime}}{f_{c o}^{\prime}}=1+3.5\left(\frac{f_{l}}{f_{c o}^{\prime}}\right)^{0.85}$ \\
\hline $\begin{array}{l}\text { Samaan et al. } \\
{[61] \text { model }}\end{array}$ & $f_{c c}^{\prime}=f_{c o}^{\prime}+6.0 f_{l}^{0.70}$ \\
\hline $\begin{array}{c}\text { Miyauchi et al. } \\
\text { [62] model }\end{array}$ & $\frac{f_{c c}^{\prime}}{f_{c o}^{\prime}}=1+3.485 \frac{f_{l}}{f_{c o}^{\prime}}$ \\
\hline
\end{tabular}

Table 1 Previous strength models of FRP confined concrete specimens 
33 specimens were confined with steel stirrups. The FRPs wraps with various elastic moduli such carbon fibers $\left(E_{f}=25 \mathrm{GPa}\right.$ to $\left.612 \mathrm{GPa}\right)$, aramid fibers $\left(E_{f}=14 \mathrm{GPa}\right.$ to $116 \mathrm{GPa})$, glass fibers $\left(E_{f}=11 \mathrm{GPa}\right.$ to $\left.101 \mathrm{GPa}\right)$ were used in these researches. This database contains all the essential parameters associated with the strength enhancement of concrete specimens confined with FRPs. Some preliminary evaluations were conducted on the previous experimental data of confined concrete which showed that some of the data points were not predicted by the existing strength models. Thus, those values of data were removed to avoid the saturation of RMSE index. The removed data points consisted of 50 values giving more than $30 \%$ error. The strength model was evaluated using 700 data points using statistical indices such as $R^{2}$ and $R M S E$. Table 2 provides statistical information about the variation of certain parameters associated with the specimens considered.

Where, $D$ is diameter of column, $H$ is height of column, $N . t_{f}$ is thickness of FRP layers, $E_{s}$ is elastic modulus of FRPs, $f_{c o}^{\prime}$ is unconfined strength of concrete, $f_{c c}^{\prime}$ is compressive strength of confined concrete, $\varepsilon_{c o}$ is axial compressive strain of unconfined concrete corresponding to $f_{c o}^{\prime}, \varepsilon_{c c}$ is ultimate axial compressive strain of confined concrete corresponding to $0.85 f_{c c}^{\prime}$.

\section{Assessment of strength models}

To predict the ultimate compressive strength of the FRP-confined concrete $\left(f_{c c}\right)$, design oriented empirical model was proposed based on the large previous experimental database of 700 FRP-confined specimens which is another new aspect of present study. The proposed model was developed using the curve fitting techniques in MATLAB by minimizing $R^{2}$ and $R M S E$ between the experimental and predicted values by previous empirical models. The strength models proposed by Teng et al. [55], Fardis and Khalili [35], Richart et al. [36], Newman and Newman [37], Mander et al. [38], Lam and Teng [39], Karbhari and Gao [57], Saafi et al. [58], Matthys et al. [59], Toutanji [60], Samaan et al. [61], and Miyauchi et al. [62]

Table 2 Statistical information of collected database

\begin{tabular}{lcccccccc}
\hline $\begin{array}{l}\text { Para- } \\
\text { meter }\end{array}$ & $\begin{array}{c}\mathrm{D} \\
(\mathrm{mm})\end{array}$ & $\begin{array}{c}\mathrm{H} \\
(\mathrm{mm})\end{array}$ & $\begin{array}{c}N . t_{f} \\
(\mathrm{~mm})\end{array}$ & $\begin{array}{c}E_{f} \\
(\mathrm{GPa})\end{array}$ & $\begin{array}{c}f_{c o}^{\prime} \\
(\mathrm{MPa})\end{array}$ & $\begin{array}{c}f_{c c}^{\prime} \\
(\mathrm{MPa})\end{array}$ & $\begin{array}{c}\varepsilon_{c o} \\
(\%)\end{array}$ & $\begin{array}{c}\varepsilon_{c c} \\
(\%)\end{array}$ \\
\hline Min & 51 & 102 & 0.09 & 10 & 12.4 & 18.5 & 0.17 & 0.3 \\
Max & 406 & 812 & 5.9 & 612 & 188.2 & 302.2 & 1.53 & 4.6 \\
Mean & 152 & 306 & 0.92 & 165.6 & 43.04 & 76.6 & 0.27 & 1.5 \\
St. Dev & 45 & 91 & 1.09 & 115.7 & 23.5 & 34.5 & 0.15 & 0.8 \\
COV & 0.3 & 0.3 & 1.19 & 0.7 & 0.55 & 0.46 & 0.56 & 0.5 \\
\hline
\end{tabular}

were evaluated using the database. These models were selected due to their easy implementation and extensive use in the literature. The relationships for $R^{2}$ and $R M S E$ are given by the Eq. (5) and Eq. (6), respectively.

$$
\begin{aligned}
& R^{2}=\left(\frac{n\left(\sum x y\right)-\left(\sum x\right)\left(\sum y\right)}{\sqrt{\left[n \sum x^{2}-\left(\sum x\right)^{2}\right]\left[n \sum y^{2}-\left(\sum y\right)^{2}\right.}}\right)^{2}, \\
& \text { RMSE }=\sqrt{\frac{\sum(x-y)^{2}}{n}},
\end{aligned}
$$

where, $n$ is the sample points; $x$ is the experimental values and $y$ are the predicted values. The value of RMSE varies from 0 to 1 giving a perfect prediction at 0 . Similarly, the value of $R^{2}$ also varies from 0 to 1 ; one shows a perfect correlation and zero represents that there is no correlation between experimental and predicted values. The difference between experimental and predicted values was taken as error and sum of the squared errors (SSE) was minimized to achieve the best fit. A smaller value of SSE shows a tight fit of the empirical model to the experimental data. The performances of the previous strength models with $R^{2}$ and RMSE were represented in Fig. 2.

Lam and Teng [39] model, which is adopted by ACI 440.2R-02 [63] with some modifications, shows a good performance with $R M S E=0.244$ and $R^{2}=0.903$. Therefore, the form of the currently proposed strength model was similar to that of the Lam and Teng [39] model except that the proposed model was nonlinear in nature. The RMSE index of the Mander et al. [38] model, initially adapted by ACI 440.2R-02 [63], shows its best performance as compared with other models but the value of $R^{2}$ is not so good as that of other models. Therefore, its form was not selected for the proposed model. After performing a comparative study of the existing models and forms, the final decision of the best form was made as represented by Eq. (7). The proposed nonlinear empirical model for the strength of FRP confined concrete is represented by Eq. (8).

$$
\frac{f_{c c}}{f_{c o}}=1+k\left(\frac{f_{l}}{f_{c o}}\right)^{n},
$$

where, $k$ and $n$ are the constants determined by using general regression analysis. The values for these constants were 3.09 and 0.828 giving the best fit to curve. After incorporating the values of constants:

$f_{c c}=f_{c o}+3.09 f_{c o}^{0.172} f_{l}^{0.828}$. 

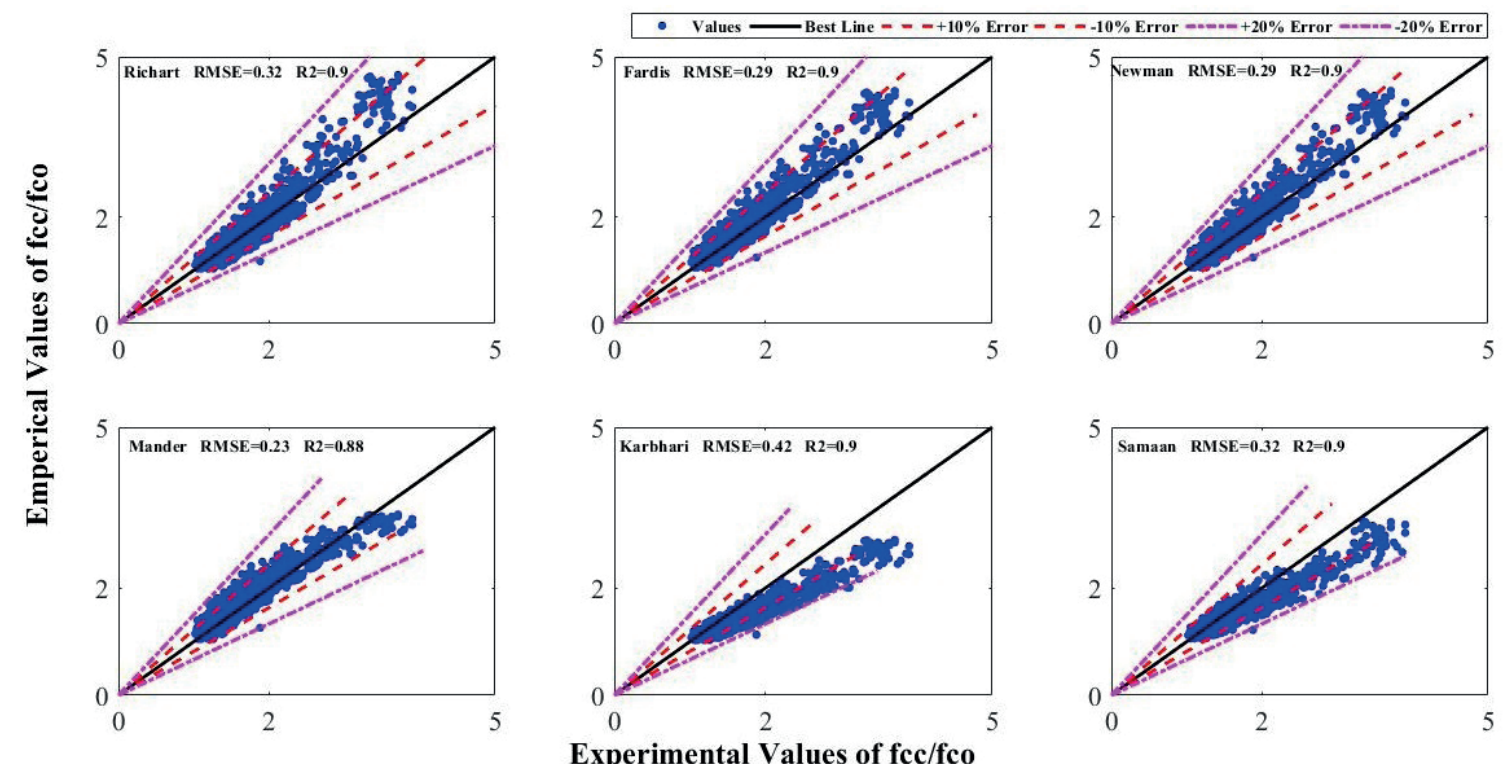

(a) Performance of strength models given by Richart et al. [36], Fardis and Khalili [35], Newman and Newman [37], Mander et al. [38], Karbhari et al. [57], and Samaan et al. [61]
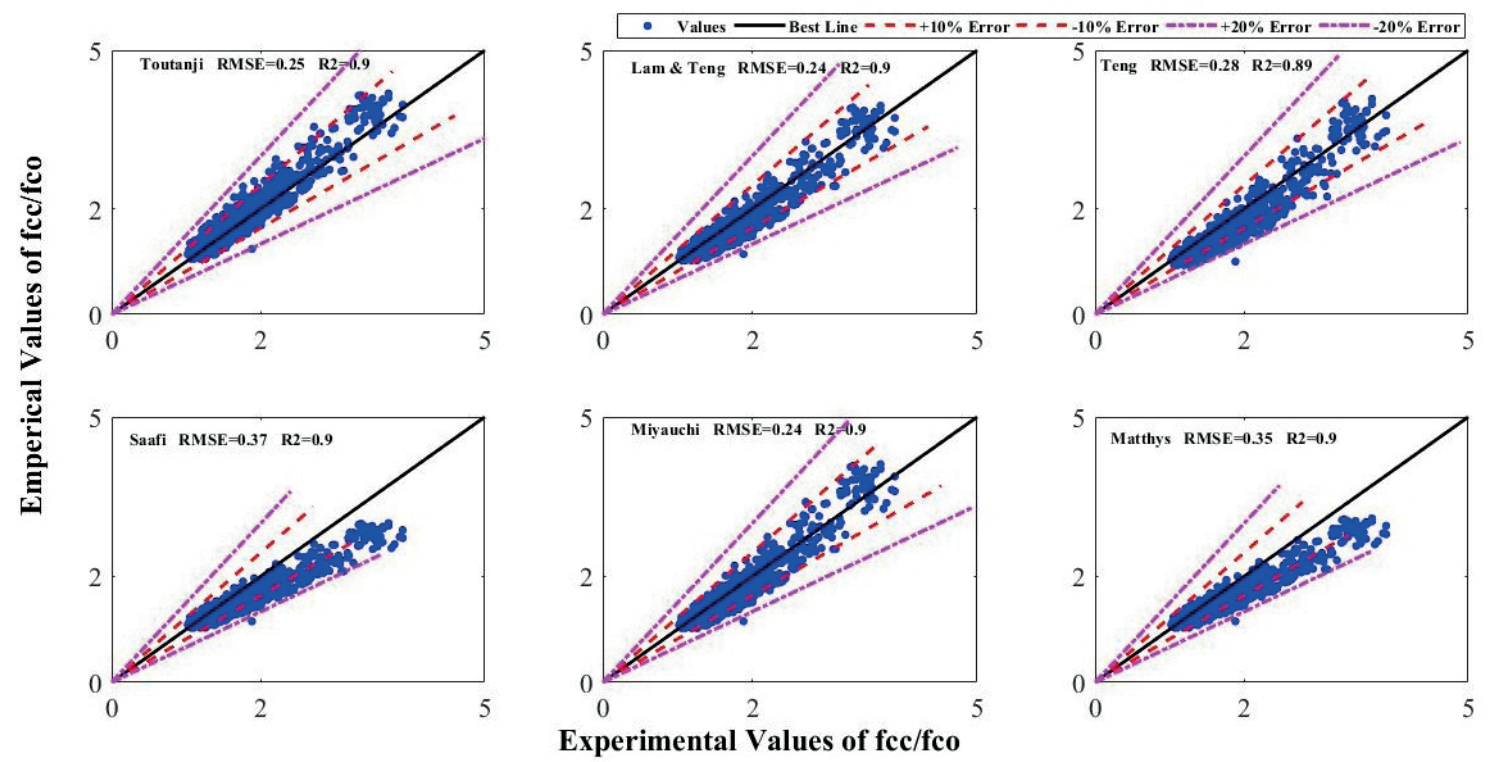

(b) Performance of strength models given by Toutanji [60], Lam and Teng [39], Teng et al. [55], Saafi et al. [58], Miyauchi et al. [62] and Matthys et al. [59]

Fig. 2 Performance of previously proposed strength models of FRP-confined concrete on the developed database

The behavior and performance of the proposed strength models is represented in Fig. 3 using the database of 700 points with the $R^{2}=0.906$ and $R M S E=0.204$. These indices show that the performance of the currently proposed confinement model is better than the previous models with significant accuracy.

The normal distribution of confined to unconfined strength ratios of experimental and theoretical predictions for the previous database were presented in Fig. 4 and the distribution of confined to unconfined strength ratio of the database was shown in Fig. 5. The proposed analytical model and Richart et al. [36] model performed well for the mean normalized values with deviations of $1.5 \%$ and $1 \%$ from unity, respectively. The normalized predictions of other previous strength models were found to be conservative. It can be observed that Karbhari and Gao [57] model represents most of $f_{c c} / f_{c o}$ ratios in the range $0-1.5$. Thus, the currently proposed model is capable of providing the close predictions after being successful in all investigations of the present work. 


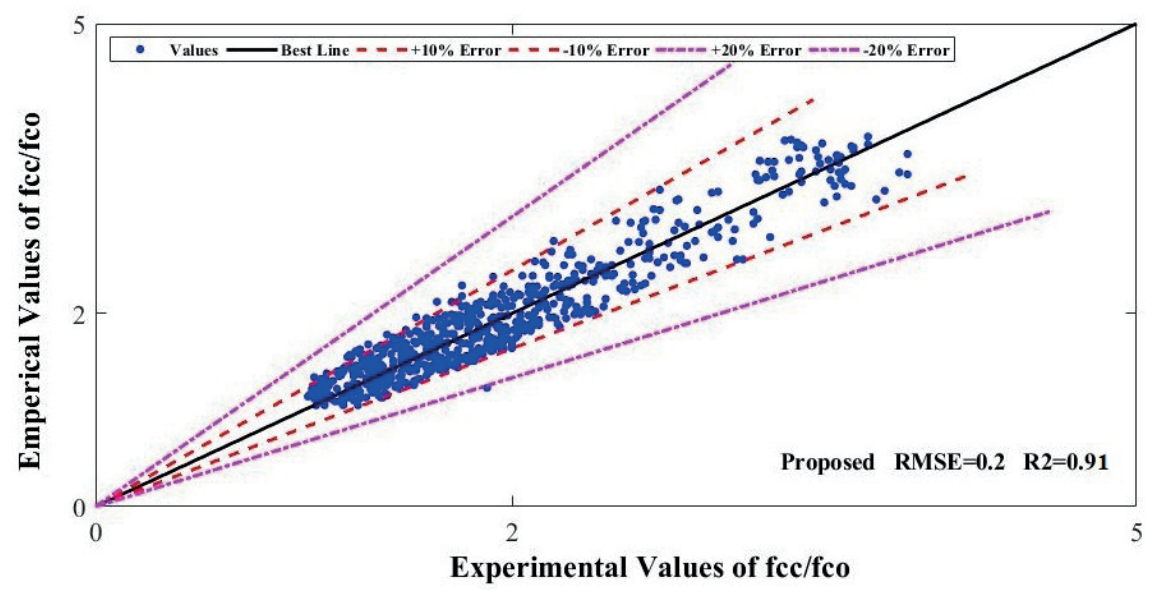

Fig. 3 Performance of proposed empirical strength model for FRP-confined specimens

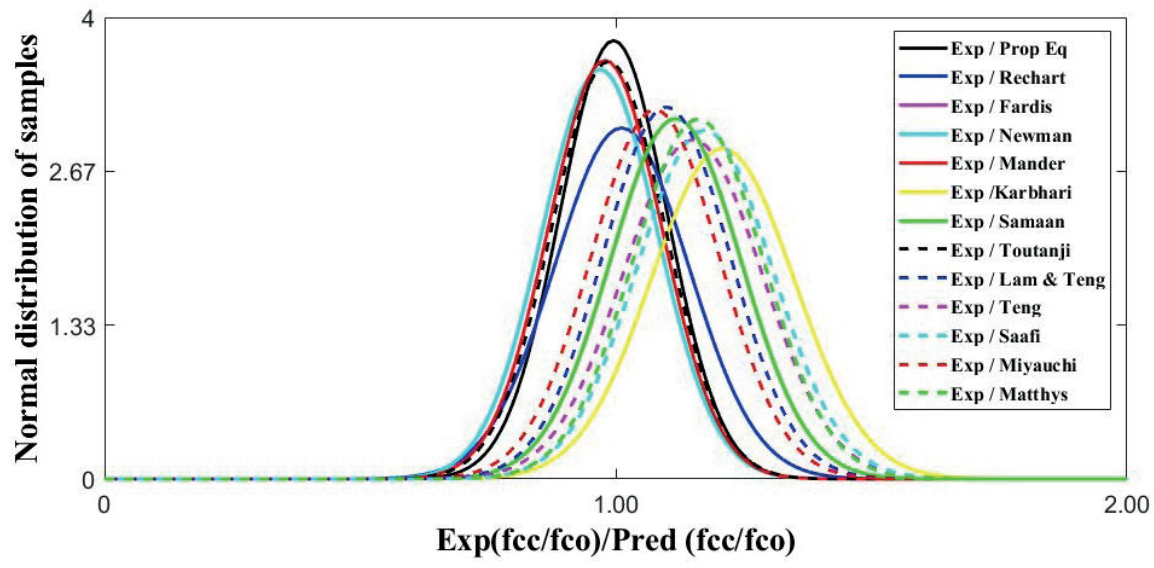

Fig. 4 Normal distribution of $\left(f_{c c} / f_{c 0_{\text {exp }}}\right) /\left(f_{c c} / f_{c o_{\text {prea }}}\right)$ for FRP-confined specimens based on predictions of various strength models

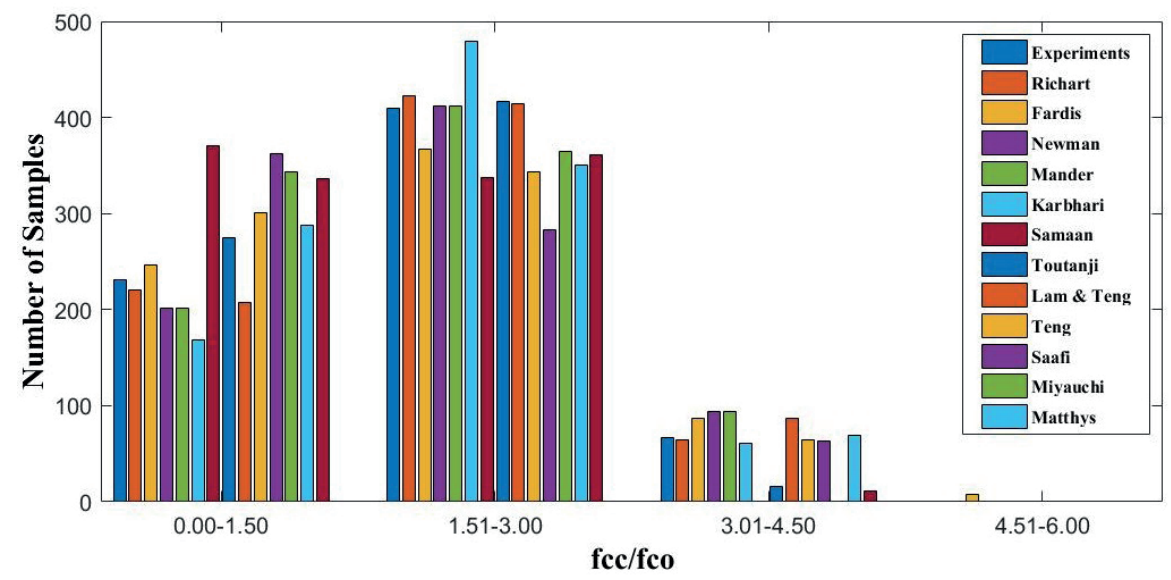

Fig. 5 Distribution of $f_{c c} / f_{c o}$ for FRP-confined specimens based on predictions of various strength models

Fig. 6 represents the flow chart of the current research work. After collection of a large database of FRP confined concrete specimens, some preliminary evaluations were made on it by considering some statistical parameters (RMSE, SSE and $R^{2}$ ). Finally, the empirical FRP confinement model was proposed using MATLAB giving the accurate results for strength of FRP confined concrete.
The constants of FRP confinement model were determined using curve fitting technique based on the constructed experimental database. Thereafter, an equation was proposed for predicting the axial loading capacity of STFC columns. The accuracy of the proposed capacity model was evaluated by comparing its predictions with the FEM predictions obtained during the detailed parametric study. 


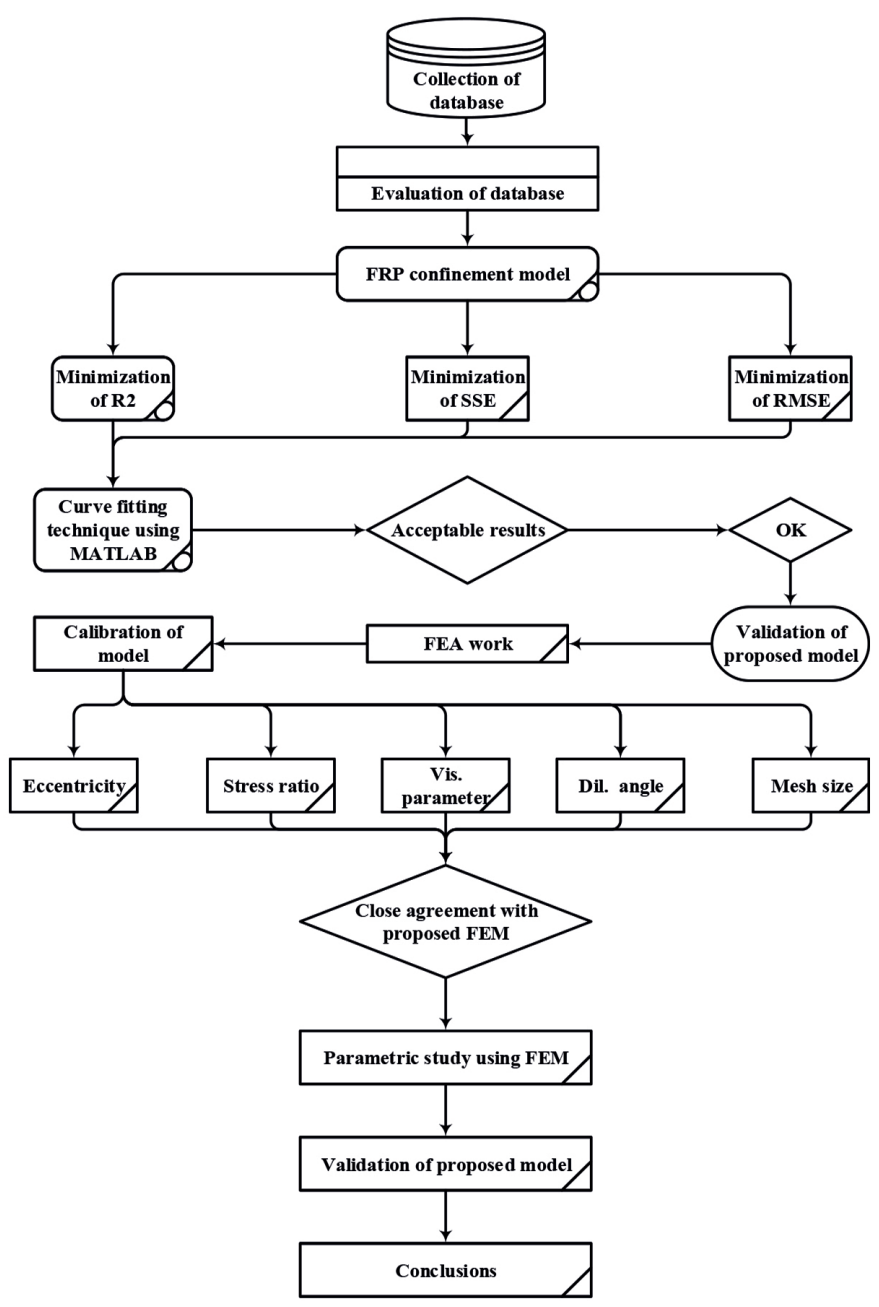

Fig. 6 Flow chart of presented research work

\section{Load-carrying capacity equation}

The analytical model to predict of the axial capacity of STFC composite columns consists of two parts: one is due to confinement stress and the second is due to ultimate capacity of steel tube. For the first part of the analytical capacity model, twelve different strength models were evaluated using some statistical parameters such as root mean square error (RMSE), coefficient of determination $\left(R^{2}\right)$ and the sum of squared errors (SSE) on the developed database to propose a general form of the analytical model. Fig. 2 represents the performance of different studied strength models taken from literature. The ultimate loading capacity $\left(P_{n}\right)$ of STFC columns can be defined as:

$P_{n}=P_{\text {confinement }}+P_{\text {steel tube }}$,

where, $P_{\text {confinement }}$ is the ultimate loading capacity of the column due to confined concrete and $P_{\text {steel tube }}$ is the ultimate loading capacity of column due to steel tube. The ultimate loading capacity due to confinement can be expressed as:

$P_{\text {confinement }}=A_{c c} f_{c c}$ where, $A_{c c}$ is the concrete cross-sectional core area confined by FRPs and steel tube together and $f_{c c}$ is the axial strength of confined concrete. In the derived equation for the axial strength of confined concrete, $f_{l}^{\prime}$ is the maximum combined confinement stress provided by FRP-wraps and steel tube together which can be represented by the Eq. (11) given below $[64,65]$ :

$$
f_{l}^{\prime}=k_{\varepsilon} f_{l}+f_{l, s}=\frac{2 E_{f} \varepsilon_{h, r u p} N t_{f}}{D-2 t_{s}} k_{\varepsilon}+\frac{2 t_{s} f_{y}}{D-2 t_{s}},
$$

where, $N \cdot t_{f}$ is the total thickness of FRP wraps, is the outside diameter of the tube, $E_{f}$ is the Young's modulus of FRPs, is the strain efficiency factor of FRP wraps with an average value of 0.594 [22], $t_{s}$ is the thickness of steel tube and $\varepsilon_{h, \text { rup }}$ is the rupture strain of FRPs in hoop direction whose relation was provided by Lim et al. [56] using genetic programming:

$$
\varepsilon_{h, \text { rup }}=\frac{\varepsilon_{f}}{f_{c o}^{0.125}} .
$$


Putting the value of $f_{c c}$ in Eq. (10) after considering the combined confinement effect of steel tube and FRP wraps,

$$
P_{\text {confinement }}=A_{c c}\left[f_{c o}+3.09 f_{c o}^{0.172} f_{l}^{\prime} 0.828\right] \text {. }
$$

The ultimate capacity of steel tube $P_{\text {steel tube }}$ can be found using the continuous strength method which has been established to exploit the strain hardening for determining the steel-tube cross-section resistances [23, 66, 67].

$$
P_{\text {steel tube }}=A_{\text {steel tube }} \sigma_{L B} \text {, }
$$

where, $A_{\text {steel tube }}$ is the gross cross-sectional area of steel tube and $\sigma_{L B}$ is the stress defining the local buckling of the tube which can be measured by using Eq. (15) and Eq. (16) proposed by Buchanan and Gardner [67]. The maximum participation of steel tube in the ultimate loading capacity and ductility of the STFC composite columns is due to its strain-hardening characteristics [53].

$\sigma_{L B}=E \varepsilon_{L B} \frac{\varepsilon_{L B}}{\varepsilon_{0.2}}<1.0$,

$\sigma_{L B}=\varepsilon_{0.2}+E_{s h} \varepsilon_{0.2}\left(\frac{\varepsilon_{L B}}{\varepsilon_{0.2}}-1\right) \frac{\varepsilon_{L B}}{\varepsilon_{0.2}} \geq 1.0$,

where, $\varepsilon_{L B}$ is the local buckling strain, $\varepsilon_{0.2}$ is the $2 \%$ proof strain of steel tube, $E$ is the Young's modulus of steel tube is elastic part of the curve and $E_{s h}$ is the Young's modulus during the strain hardening in the bi-linear performance of steel tube. The expression between the cross-sectional slenderness of the tube and deformation capacity can be represented by the Eq. (17) as proposed by Buchanan and Gardner [67].

$$
\frac{\varepsilon_{L B}}{\varepsilon_{0.2}}=\frac{4.44 \times 10^{-3}}{\lambda_{c}^{4.5}} \leq \text { minimum }\left(15, \frac{0.1 \varepsilon_{u}}{\varepsilon_{0.2}}\right)
$$

The cross-sectional slenderness $\left(\lambda_{c}\right)$ is represented by:

$$
\lambda_{c}=\sqrt{\frac{\sigma_{0.2}}{\sigma_{c r}}},
$$

where, $\sigma_{0.2}$ is the $2 \%$ proof stress obtained from the stressstrain performance of steel tube and $\sigma_{c r}$ is the local critical stress in the elastic region of steel tube.

Thus, the ultimate loading capacity $\left(P_{n}\right)$ of the STFC composite columns can be rewritten in the following general form.

$$
P_{n}=A_{c c}\left[f_{c o}+3.09 f_{c o}^{0.172} f_{l}^{\prime 0.828}\right]+A_{\text {steel tube }} \sigma_{L B}
$$

This is the proposed equation predicting the maximum loading capacity of STFC columns under concentric loadings.

\section{Validation of proposed equation}

For the validation of the proposed model a numerical model for STFC columns was proposed and validated against the previous experimental results from Liu et al. [22]. Thereafter, the proposed FEA model was used to perform a parametric study for the development of a database of STFC columns. Finally, the results obtained from parametric study were used for the comparison to the predictions of the proposed empirical model based on curve fitting techniques. The numerical model should not be complex which will increase the analysis time but should be rich enough to capture the essential and critical phenomenon of the structural member.

\subsection{Finite Element Modelling}

The FEA models of all the STFC columns were simulated whose bottom was restrained for all degrees of freedom (DOF) and the top end was kept unrestrained with the applied uniformly distributed axial load on the upper steel plate using displacement control technique. Eight full-scale specimens of STFC columns were modelled in ABAQUS under axial compressive loading. The material and geometrical properties of the simulated columns are shown in Table 3. During the FEA simulation, the nonlinear geometric parameter was also included with the specified dissipation energy fraction of 0.0002 to deal with relatively larger displacements. The confined concrete material and the steel plates were modelled as deformable three-dimensional stress, 8-nodded solid brick elements with the hourglass control and reduced integration (C3D8R). The steel tube and CFRP sheets were simulated using the deformable 4-nodded doubly curved shell elements along with the hour glass control and the reduced integration (S4R) having six DOF at each node is capable of predicting the buckling behavior accurately [23]. The interaction between the outer concrete surface and the inner steel tube surface was taken as a hard contact in normal direction to avoid the penetration of surfaces into each other and a frictional contact was specified in tangential direction of the member using a frictional coefficient of 0.25 as proposed by [54]. Similarly, the connection between the concrete surfaces and the rigid steel plates surfaces was simulated using the hard contact interaction and the frictional contact interaction with a friction coefficient of 0.35 in the normal direction and the tangential direction, respectively [68]. The surface of concrete core material was taken as master and the surface of steel plates was assigned as slave surface. The contact between the inner surface of CFRP sheets and 
the shell elements of steel tube was defined using the constraint "tie" available in the ABAQUS by specifying the interior surface of CFRP sheets and the exterior surface of steel tube as slave surface and master surface, respectively. The node region of steel tube was tied with the surface of steel rigid plates by considering them as a master surface. Fig. 7 shows the geometry, steel tube to concrete surface friction interaction, applied loading and meshed elements of the STFC columns. The thickness of each CFRP layer was $0.167 \mathrm{~mm}$ and the ultimate strength was $3400 \mathrm{MPa}$. The yield strength and elastic modulus of steel tube were taken as $264.3 \mathrm{MPa}$ and $1.88 \times 10^{5} \mathrm{MPa}$, respectively.

\subsection{Calibration of model}

A STFC column (L2-C40-D200) from previous work [22] was taken as a control specimen for calibration and validation purposes. The FEA model of L2-C40-D200 was calibrated for different boundary conditions, geometric properties, and material properties in order to obtain the accurate results as compared with that of experiments of the axial capacity, load-deflection behavior, and failure patterns.

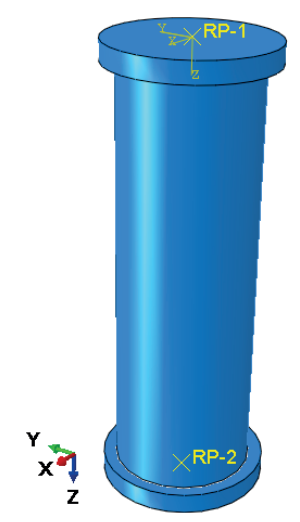

(a)

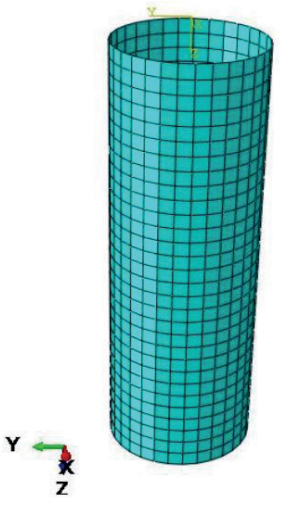

(b)

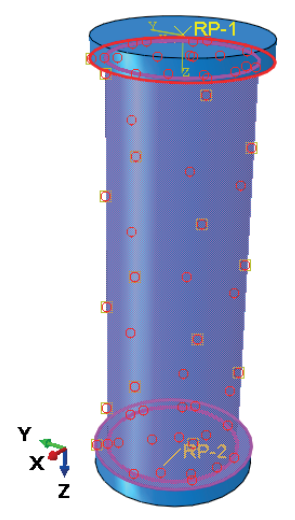

(c)
The definition of the plastic region of concrete behavior requires the description of flow rule, hardening and softening laws and shape function of yielding surface. The dilation angle of concrete, which is a material parameter, belongs to the non-associated flow rule. The CDP model for the accurate simulations of the plastic behavior of concrete uses the flow potential function which is basically defined by Drucker-Prager hyperbolic function as represented by Eq. (20).

$G(\sigma)=\sqrt{\left(\varepsilon \sigma_{t 0} \tan \psi\right)^{2}+\bar{q}^{2}}-\bar{p} \tan \psi$,

where, $\psi$ is the dilation angle of concrete, $\varepsilon$ is the eccentricity of the flow potential function and $\sigma_{t 0}$ is the uniaxial failure tensile stress. The Drucker-Prager potential function is represented by Eq. (21).

$G=\sqrt{2 J_{2}}+\alpha_{p} I_{1}$,

where, $\alpha_{p}$ is a parameter of concrete called as dilatancy parameter. Eq. (20) and Eq. (21) can be rewritten as:

$G(\sigma)=\sqrt{\left(\varepsilon \sigma_{t 0} \tan \psi\right)^{2}+\bar{q}^{2}}-\frac{1}{3} I_{1} \tan \psi$

Fig. 7 Finite element simulations (a) geometry, (b) CFRP and steel tube elements (c) interactions between various parts (d) meshed elements of the STFC columns (e) applied loading

Table 3 Details of geometry and material properties of simulated STFC column specimens

\begin{tabular}{|c|c|c|c|c|c|c|}
\hline Specimen label & $\begin{array}{l}\text { Outside diameter } \\
\text { of steel tube (mm) }\end{array}$ & $\begin{array}{l}\text { Height of concrete } \\
\text { column }(\mathrm{mm})\end{array}$ & $\begin{array}{l}\text { Thickness of steel } \\
\text { tube }(\mathrm{mm})\end{array}$ & $\begin{array}{l}\text { No. of CFRP } \\
\text { layers }\end{array}$ & $\begin{array}{l}\text { Total thickness of } \\
\text { CFRP layers (mm) }\end{array}$ & $\begin{array}{c}\text { Cubic compressive } \\
\text { strength of concrete }(\mathrm{MPa})\end{array}$ \\
\hline L2-C40-D200 & 200 & 600 & 2 & 2 & 0.334 & 57.1 \\
\hline L4-C40-D200 & 200 & 600 & 2 & 4 & 0.668 & 57.1 \\
\hline L2-C60-D200 & 200 & 600 & 2 & 2 & 0.334 & 66.8 \\
\hline L4-C60-D200 & 200 & 600 & 2 & 4 & 0.668 & 66.8 \\
\hline L2-C40-D260 & 260 & 780 & 2 & 2 & 0.334 & 57.1 \\
\hline L4-C40-D260 & 260 & 780 & 2 & 4 & 0.668 & 57.1 \\
\hline L2-C60-D260 & 260 & 780 & 2 & 2 & 0.334 & 66.8 \\
\hline L4-C60-D260 & 260 & 780 & 2 & 4 & 0.668 & 66.8 \\
\hline
\end{tabular}


Wu et al. [69] and Voyiadjis and Taqieddin [70] suggested that the value of $\alpha_{p}$ should be between 0.2 and 0.3 . Using this range of $\alpha_{p}$, the value of $\psi$ should be in between 310 and $42 \mathrm{o}$. Therefore, this parameter of the plastic behavior of concrete was calibrated using the load-deflection curve of control specimen (L2-C40-D200) for the values of $30 \mathrm{o}, 33 \mathrm{o}, 36 \mathrm{o}, 39 \mathrm{o}, 42 \mathrm{o}$ and $45 \mathrm{o}$ in order to achieve the accurate predictions. The best approximation was achieved using 30o for $\psi$ which was selected for the control model (L2-C40-D200) as shown in Fig. 8(a). It was examined that the effect of $\psi$ was significant in the post-buckling behavior of concrete but was negligible inelastic behavior.

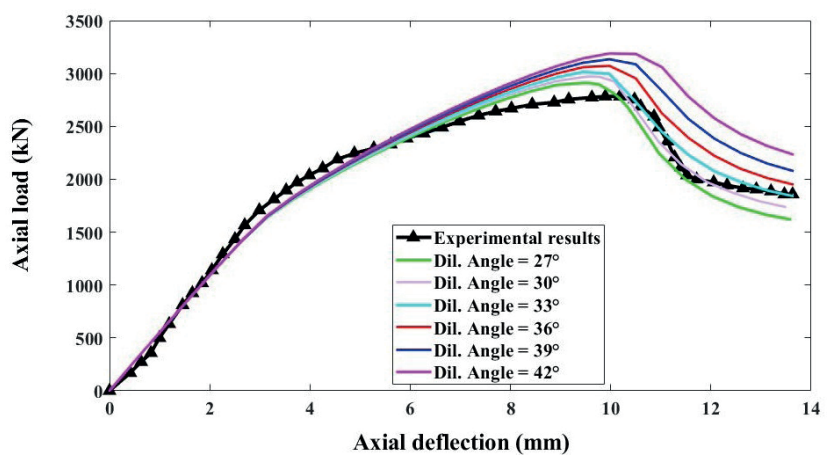

(a)

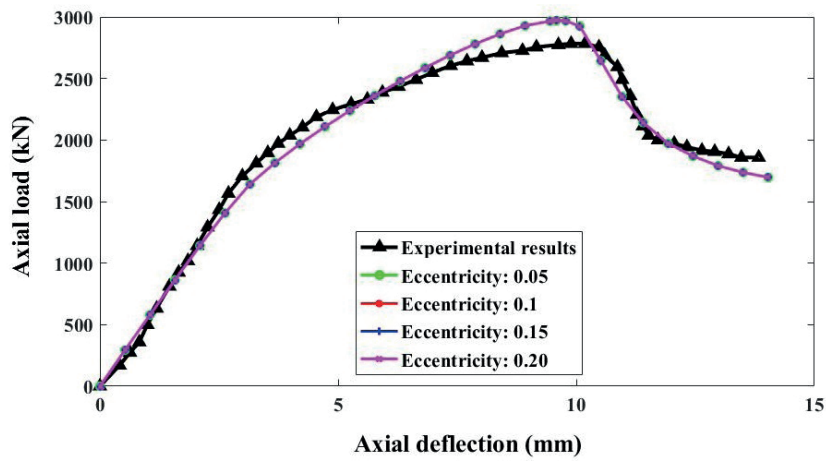

(c)

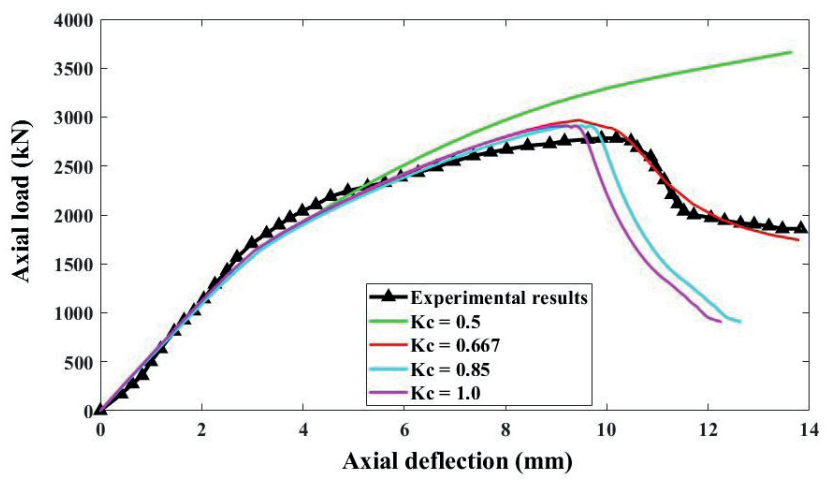

(e)
The sensitivity of the load-deflection performance of the control specimen due to viscosity parameter of concrete as shown in Fig. 8(b). For the better convergence of FEA results, a smaller value should be used for the viscosity parameter. The time increment size influences this parameter and its value should always be approximate $15 \%$ of time increment size for achieving the good results as compared with experimental results [71]. The ultimate axial strength of control specimen was increased up to $27 \%$ when the viscosity parameter was increased from 0.0009 to 0.009 . The selected value of this parameter was 0.005 because of the good results at this value in comparison with the experimental load-deflection response.

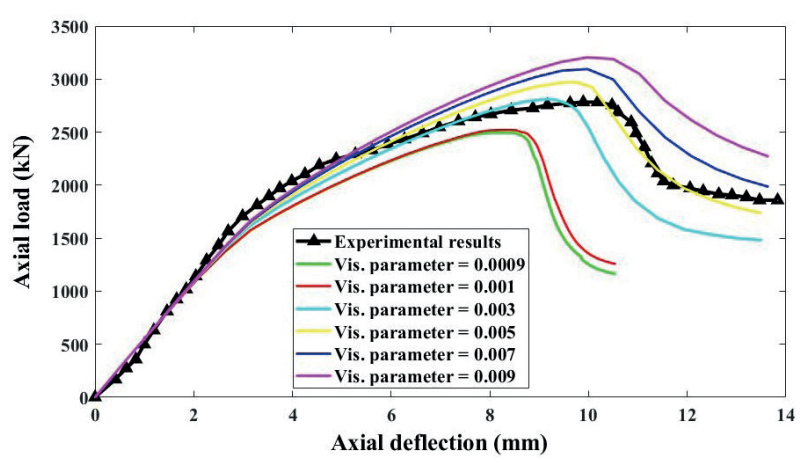

(b)

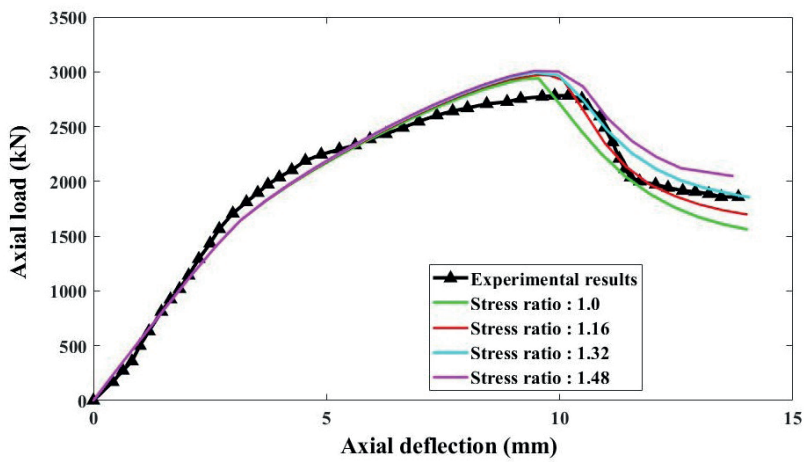

(d)

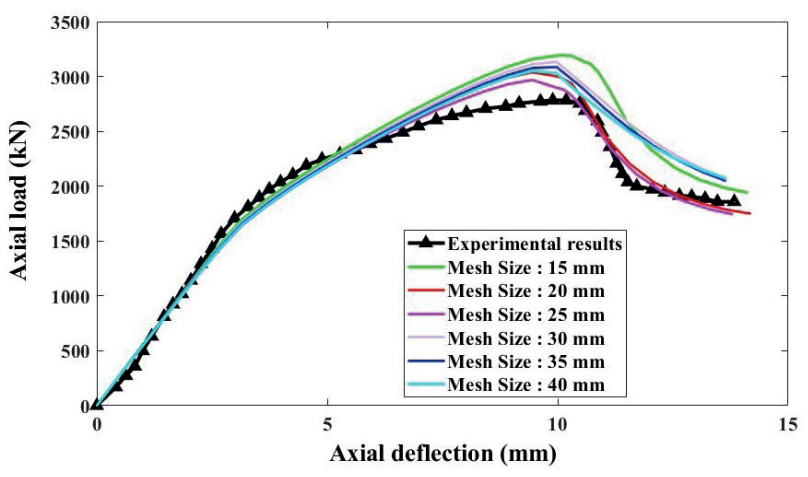

(f)

Fig. 8 Sensitivity of different parameters on load-deflection performance of control model (a) dilation angle, (b) viscosity parameter, (c) eccentricity, (d) stress ratio, (e) shape factor, (f) mesh size of elements 
The sensitivity due to eccentricity ( was also investigated for the convergence of the control FEA model. After the sensitivity analysis, it was investigated that the variation of $\varepsilon$ has no significant effect on the axial load-deflection response of the control model. Therefore, the default value for $\varepsilon$ was used in the current research as shown in Fig. 8(c). The sensitivity analysis to determine the effect of uniaxial to biaxial stresses ratio $\left(\sigma_{b 0} / \sigma_{c 0}\right)$ was performed concluding that the value of 1.16 gives better results as presented in Fig. 8(d).

The study of the effect of $K_{c}$ on the load-deflection behavior predicted the value of $K_{c}$ as 0.667 as represented in Fig. 8(e). Using a relatively smaller value of $K_{c}(0.5)$ does not allow the concrete for degradation and using a larger value (1.0) allows the control specimen to fail at smaller load and smaller deflection. The value of 0.667 gave the best approximation with the experimental results and hence, was selected.

Element sizes of 15, 20, 25, 30, 35 and $40 \mathrm{~mm}$ were studied to determine the mesh size giving the best approximation to the experimental curve of load-deflection of STFC columns. At $15 \mathrm{~mm}$ mesh size, the ultimate load and corresponding axial deflections were $108 \%$ and $107 \%$ than that of $25 \mathrm{~mm}$ mesh size. A close agreement between the FEA and the experimental predictions of load-deflection response was obtained using the elements of $25 \mathrm{~mm}$ size which was selected for the further analysis of the STFC columns and their parametric study. The effect of different mesh sizes is represented in Fig. 8(f).

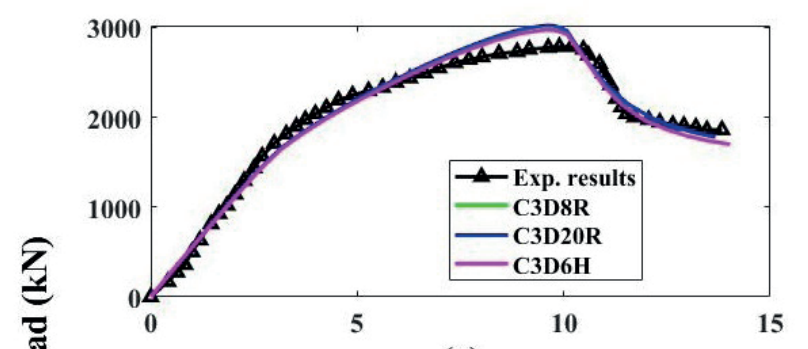

(a)

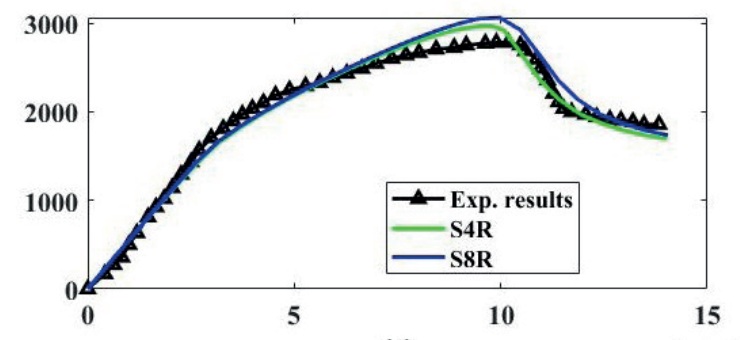

(c)
The element library of ABAQUS consists of various types of 3D stress and shell elements. The 3D concrete material was calibrated for triangular elements $(\mathrm{C} 3 \mathrm{D} 15 \mathrm{H}$ and $\mathrm{C} 3 \mathrm{D} 6 \mathrm{H})$, hexahedral elements (C3D20R and C3D8R) and tetrahedral elements $(\mathrm{C} 3 \mathrm{D} 10 \mathrm{H}$ and $\mathrm{C} 3 \mathrm{D} 4 \mathrm{H})$. A close relation between FEA predictions and that of experiments was obtained using 8-noded brick elements (C3D8R) of concrete which is also reported by the literature [72-74]. The calibration for elements types of steel tube and CFRP sheets was conducted using the quadrilateral and triangular shell elements. The quadrilateral elements consist of linear and quadratic conventional shell elements (doubly curved) with reduced integration for large strains (S4R and S8R) and the triangular elements consist of linear and quadratic shell elements (S3R and STRI65) which were used in the current research for the convergence purpose of control model as represented in Fig. 9. A standard 4-noded shell element (doubly curved) with hourglass control and reduced integration presented the close agreement among experimental and FEA predicted results of the load-deflection behavior of control specimen (L2-C40-D200). Generally, it was concluded that the sensitivity of varying the elements types on the load-deflection performance was not significant.

\subsection{Load-deflection behavior}

The structural response of STFC columns in terms of axial load-deflection curves was represented in Fig. 10. The parameters of the plastic behavior of concrete in the modified CDP model were taken as same for all the specimens

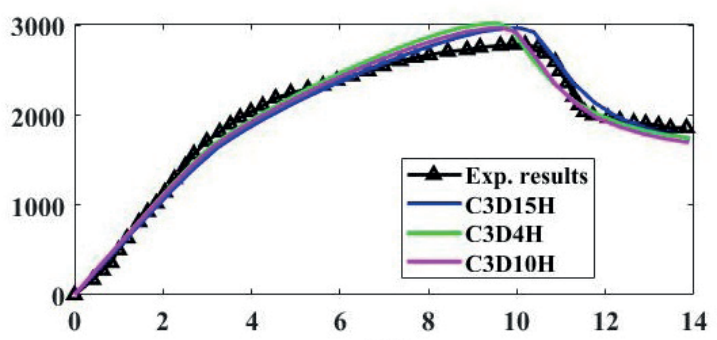

(b)

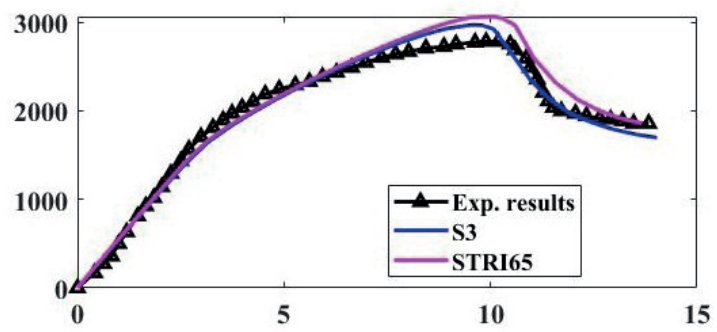

(d)

Fig. 9 Load-deflection behavior of control finite element model for different element types (a) linear plain stress, (b) quadratic plain stress, (c) quadrilateral elements of steel tube and CFRP shell elements, (d) triangular elements of steel tube and CFRP shell elements 
after calibration. It can be observed from the Fig. 10 that the FEA model captured the experimental results accurately in the elastic as well as inelastic behavior of columns.

The maximum percentage difference between the experimental and numerical results of the ultimate axial capacity was observed for the specimen having compressive strength of $40 \mathrm{MPa}, 4 \mathrm{CFRP}$ layers with a concrete core diameter of $260 \mathrm{~mm}$ (L4-C40-D260) that was $8.91 \%$. It was also noticed that the experimental results of eight STFC (with CFRP sheets) columns were stiffer that the predictions of the FEA model in elastic region but, in the inelastic region, there was a good agreement between them. Similarly, the maximum percentage difference for the deflection at ultimate load was observed for the specimen L2-C40-D260 with a value of $7.85 \%$. The

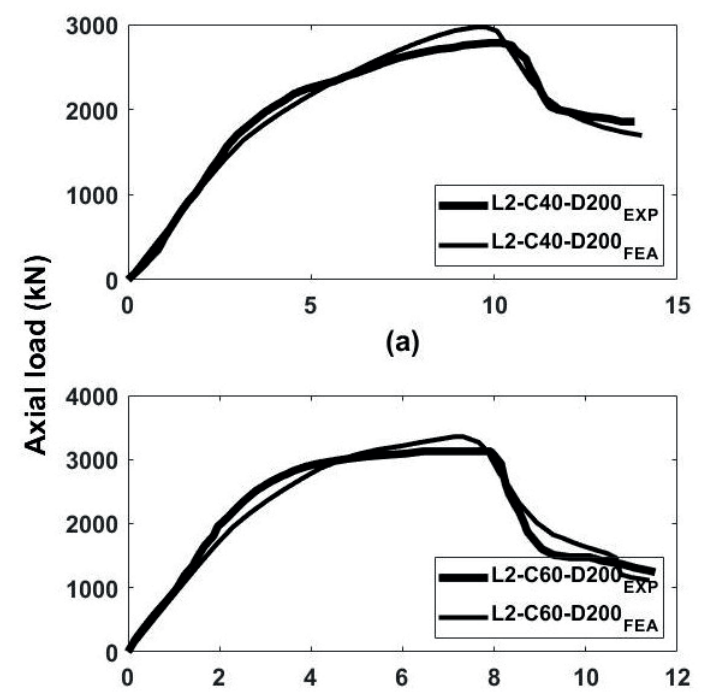

(c)

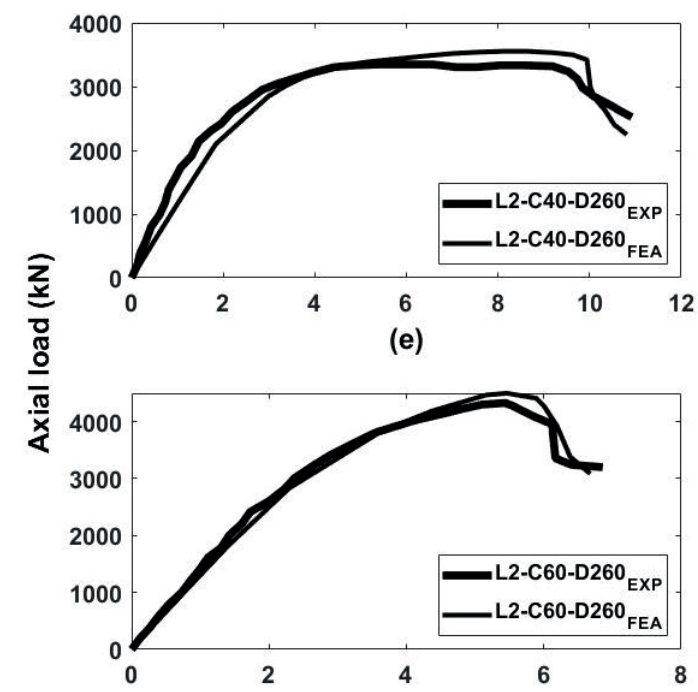

(g) average percentage discrepancies in the ultimate strength and the deflection at that strength of the STFC columns were $5.76 \%$ and $2.86 \%$, respectively. These discrepancies may be ascribed to the small imprecisions resulting from the differences between the actual testing conditions such as boundary conditions, initial geometric imperfections, strength of concrete material, strength of steel material, manufacturing faults, accuracy of the testing instruments and the conditions assumed in the FEA modelling. The difference may also be attributed to definition of the damage evolution parameters of CFRP material and the friction coefficients assumed for the contact property between the steel and concrete materials. However, the proposed constitutive FEA model seems to accurately capture the behavior of STFC columns.

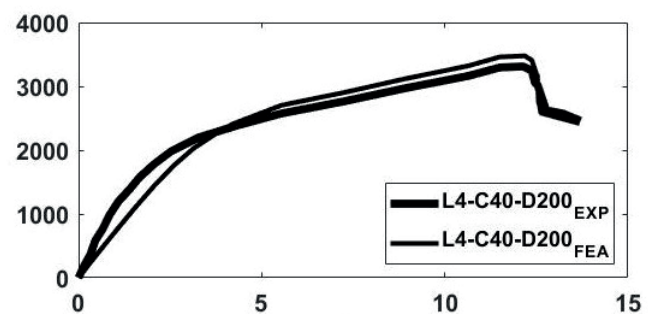

(b)

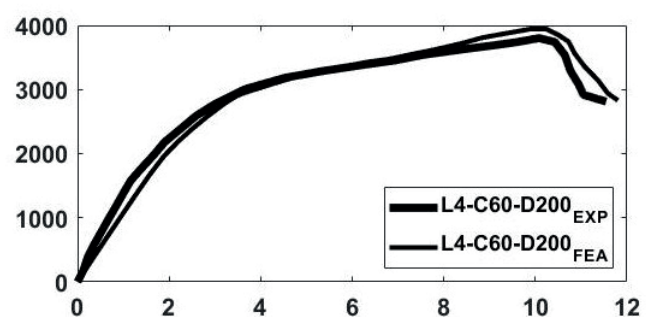

(d)

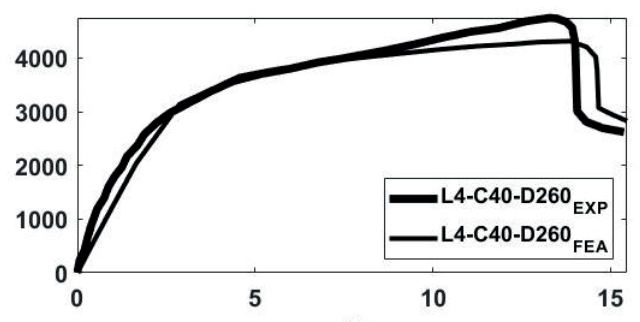

(f)

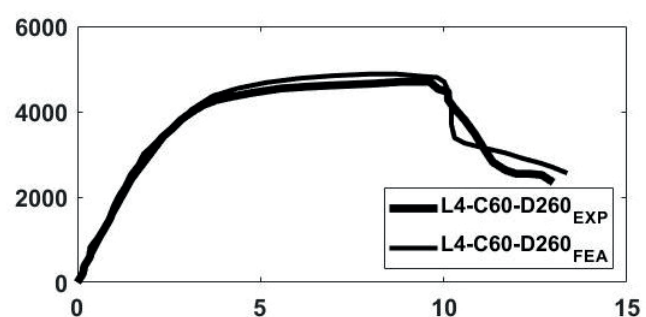

(h)

Fig. 10 Experiments and FEA results of load-deflection response of steel-tube CFRP confined concrete columns (a) L2-C40-D200, (b) L4-C40-D200, (c) L2-C60-D200, (d) L4-C60-D200, (e) L2-C40-D260, (f) L4-C40-D260, (g) L2-C60-D260, (h) L4-C60-D260 


\subsection{Parametric studies}

After validating the selected FEA model through experimental results of eight STFC columns, 216 models were analyzed to examine the effect of CFRP layers, unconfined concrete strength $\left(f_{c o}^{\prime}\right)$, thickness of steel tube $\left(t_{s}\right)$ and diameter of outside steel tube $(D)$ on the axial capacity. Different values of the parameters for the parametric study were given in Table 4. The height of all the specimens was $600 \mathrm{~mm}$. The yielding strength $(264.3 \mathrm{MPa})$ and elastic modulus $\left(1.88 \times 10^{5} \mathrm{MPa}\right)$ of steel tube and the ultimate strength CFRP sheets (3400 MPa) were taken according to Liu et al. [22].

\subsubsection{Effect of CFRP layers}

Six levels of CFRP layers were studied: 0, 1, 2, 3, 4 and 5 layers, respectively. Throughout the parametric study, the thickness of each CFRP layer was taken as $0.167 \mathrm{~mm}$. It was observed that when CFRP layers were increased from 0 to 5 at contact $t_{s}$ of $2 \mathrm{~mm}$ and constant $\mathrm{D}$ of $200 \mathrm{~mm}$ of the column with the increase of $f_{c o}^{\prime}$ from $15 \mathrm{MPa}$ to $65 \mathrm{MPa}$, the percentage increase in the capacity of STFC column was $179.01 \%$. Similarly, with the increase of CFRP layers from 0 to 5 while increasing the $t_{s}$ from $0.5 \mathrm{~mm}$ to $3 \mathrm{~mm}$ at constant $f_{c o}^{\prime}$ of $25 \mathrm{MPa}$ and constant D of $200 \mathrm{~mm}$, the percentage increase in the capacity was $64.02 \%$. Moreover, the effect of increase of CFRP layers was $1282.69 \%$ for the axial capacity with the increase of $\mathrm{D}$ from $100 \mathrm{~mm}$ to $350 \mathrm{~mm}$ at constant $f_{c o}^{\prime}$ of $25 \mathrm{MPa}$ and $t_{s}$ of $2 \mathrm{~mm}$. The
Table 4 Variables for finite elements parameter study

\begin{tabular}{lcc}
\hline Parameters & Constant Values & Varying Values \\
\hline CFRP layers & 2 & $0,1,2,3,4,5$ \\
$f_{c o}^{\prime}(\mathrm{MPa})$ & 25 & $15,25,35,45,55,65$ \\
$t_{s}(\mathrm{~mm})$ & 2 & $0.5,1,1.5,2,2.5,3$ \\
$D(\mathrm{~mm})$ & 200 & $100,150,200,250,300,350$ \\
\hline
\end{tabular}

sensitivity of CFRP layers on the ultimate axial capacity of columns with the increase of $f_{c o}^{\prime}, t_{s}$ and $D$ was separately presented in three-dimensional Fig. 11(a-c). It can be monitored that the effect of increase of number of CFRP layers along with the increase of diameter was more dominant with the percentage increase of $1282.69 \%$ in axial capacity.

\subsubsection{Effect of unconfined concrete strength $\left(f_{c o}^{\prime}\right)$}

The effect of variation of $f_{c o}^{\prime}$ on the ultimate axial capacity was represented in Fig. 11 (a, d, e). The plastic parameters of concrete were kept same for the parametric study, but the compressive and tensile behavior was changed accordingly. It was observed that with the increase of $f_{c o}^{\prime}$ from 15 to $65 \mathrm{MPa}$ along with the increase of CFRP layers from 0 to 5 at constant $t_{s}$ of $2 \mathrm{~mm}$ and constant D of $200 \mathrm{~mm}$, the percentage increase of $179.01 \%$ and $15.75 \%$ occurred for axial capacity. When $f_{c o}^{\prime}$ was increased with the increase of $t_{s}$ from $0.5 \mathrm{~mm}$ to $3 \mathrm{~mm}$, the percentage increase of $222.23 \%$ was observed for ultimate capacity. Similarly, the effect of increase of $f_{c o}^{\prime}$ was $2157.44 \%$ due to increase of diameter of columns for axial capacity.

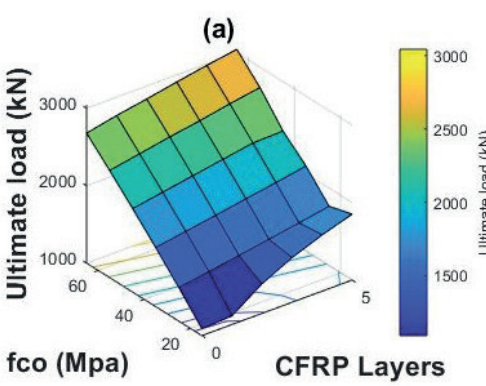

(d)

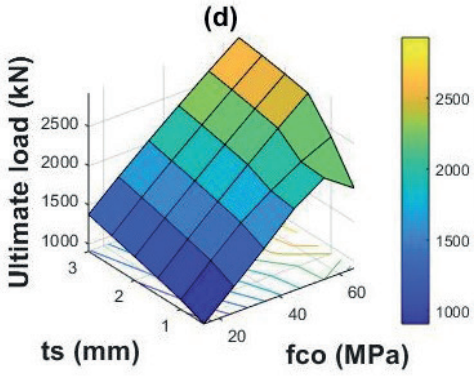

(b)

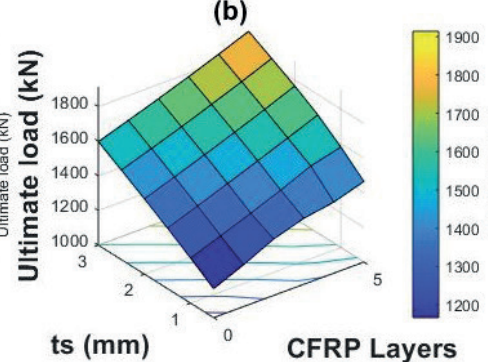

(e)

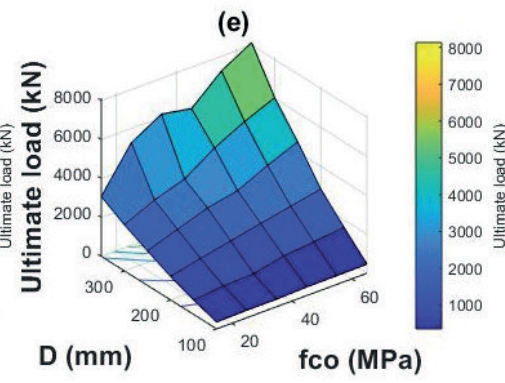

(c)
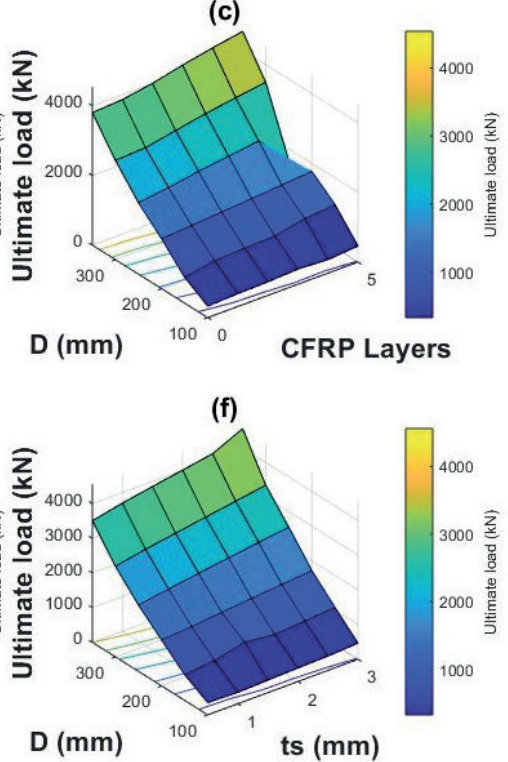

Fig. 11 Effect of CFRP layers, concrete strength, steel tube thickness and diameter of columns on the ultimate axial capacity of columns (a) effect of $f_{c o}$ and CFRP layers, (b) effect of $t_{s}$ and CFRP layers, (c) effect of $D$ and CFRP layers, (d) effect of $t_{s}$ and $f_{c o}$, (e) effect of $D$ and $f_{c o}$, (f) effect of $D$ and $t_{s}$ 


\subsubsection{Effect of steel tube thickness $\left(\boldsymbol{t}_{s}\right)$}

The thicknesses of $0.5,1,1.5,2,2.5$ and $3 \mathrm{~mm}$ of steel tube were investigated to observe their effect on the capacity of columns. By increasing the $t_{s}$ from $0.5 \mathrm{~mm}$ to $3 \mathrm{~mm}$ along with the increase of number of CFRP layers from 0 to 5 layers, the percentage increase of $64.02 \%$ occurred in ultimate capacity. Similarly, with the increase of $t_{s}$ from $0.5 \mathrm{~mm}$ to $3 \mathrm{~mm}$, the percentage increase of $1192.63 \%$ for capacity occurred with the incrementation of diameter from $100 \mathrm{~mm}$ to $350 \mathrm{~mm}$ at constant $f_{c o}^{\prime}$ of $25 \mathrm{MPa}$ and two CFRP layers as shown in Fig. 11.

\subsubsection{Effect of diameter of column (D)}

The diameter of columns $(D)$ was studied up to 6 levels: $100,159,200,250,300$ and $350 \mathrm{~mm}$ to determine its sensitivity on the load-deflection behavior of STFC columns. The effect of variation of $D$ was presented in Fig. 11(c, e, f) for ultimate capacity. It was observed that the effect of increase on diameter of column remained more significant for the increase of ultimate capacity of columns. The percentage increases of $1282.69 \%, 2157.44 \%$ and $1192.63 \%$ were observed for ultimate capacity while increasing the diameter up to $350 \mathrm{~mm}$ with the increase of number of CFRP layers from 0 layer to 5 layers, $f_{c o}^{\prime}$ from $15 \mathrm{MPa}$ to $65 \mathrm{MPa}$ and $t_{s}$ from $0.5 \mathrm{~mm}$ to $3 \mathrm{~mm}$, respectively.

Hence, it can be deduced from the extensive parametric study that the effect of increasing the CFRP layers, unconfined strength pf concrete, thickness of steel tube, and diameter of the STFC columns was significant for the increase in their capacity with the dominant effect of increase of diameter.

\subsection{Comparison of predictions}

For the validation of the proposed empirical model, a comparative study was performed between the FEA results of 216 specimens achieved from the numerical parametric study and the predictions of the proposed analytical model. Fig. 12 shows the comparison between the predictions of proposed analytical model and the proposed constitutive FEA model with the coefficient of determination $\left(R^{2}\right)$ of $0.93 \%$.

\section{Summary and conclusions}

The aim of this study is to evaluate the effectiveness and reliability of FRP confinement on concrete compression members and to propose a new empirical equation of load-carrying capacity of STFC columns. For validation of proposed equation, a constitutive FEA model of STFC composite columns was proposed using a modified CDP model after calibrating for different variables and boundary conditions. The FEA results of STFC columns were evaluated in comparison with that of previous experiments and observations which confirmed the capability of the proposed constitutive numerical model to capture the behavior of STFC columns accurately. A numerical parametric study using the proposed FEA model was also carried out to examine the effect of different critical parameters, geometric configurations and material characteristics on the structural performance of composite columns. Finally, the validation of proposed equation was performed using the FEA results of 216 specimens. The main conclusions drawn from the current research work are as given:

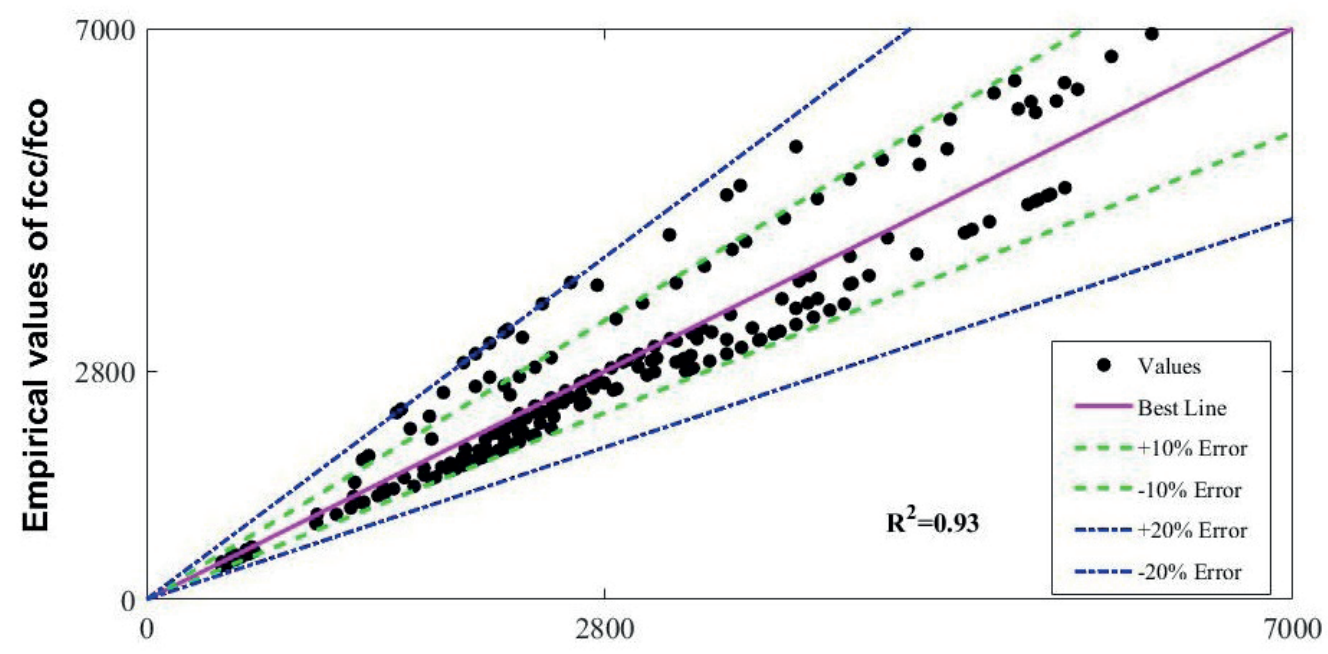

FEA values of fcc/fco

Fig. 12 Comparative study of axial capacity obtained from FEA and proposed model 
1. The currently proposed strength model for FRPconfinement on compression members performed well on the previous experimental database of 700 samples with $R^{2}=0.91$ and $R M S E=0.20$. This represents that the currently proposed FRP-confinement strength model is more accurate as compared with previously proposed models in literature.

2. The proposed capacity equation for STFC columns considers the confinement effects due to both steel tube and FRP-wrapping to effectively predict their performance.

3. The FEM proposed in the present study shows that the average percentage discrepancies between experimental and finite element results for STFC specimens were $5.76 \%$ and $2.86 \%$ for axial loads and corresponding axial deflections, respectively. It shows that the FEM traced the experimental behavior of STFC columns accurately.

4. The parametric study using the proposed FEM represents that with the increase of unconfined concrete strength from $5 \mathrm{MPa}$ to $50 \mathrm{MPa}$, there is a significant increase in confined concrete strength increases up to $193 \%$. By increasing the thickness of FRPs from $0.15 \mathrm{~mm}$ to $1.05 \mathrm{~mm}$, there is a minor increase in

\section{References}

[1] Demers, M., Neale, K. W. "Confinement of reinforced concrete columns with fibre-reinforced composite sheets - an experimental study", Canadian Journal of Civil Engineering, 26(2), pp. 226-241, 1999.

https://doi.org/10.1139/198-067

[2] Gardner, L., Cruise, R. B., Sok, C. P., Krishnan, K., Ministro, J. "Life-cycle costing of metallic structures", Proceedings of the Institution of Civil Engineers - Engineering Sustainability, 160(4), pp. 167-177, 2007.

https://doi.org/10.1680/ensu.2007.160.4.167

[3] Fam, A., Qie, F. S., Rizkalla, S. "Concrete-Filled Steel Tubes Subjected to Axial Compression and Lateral Cyclic Loads", Journal of Structural Engineering, 130(4), pp. 631-640, 2004. https://doi.org/10.1061/(ASCE)0733-9445(2004)130:4(631)

[4] O'Shea, M. D., Bridge, R. Q. "Design of Circular Thin-Walled Concrete Filled Steel Tubes", Journal of Structural Engineering, 126(11), pp. 1295-1303, 2000.

[5] Xiao, Y. "Applications of FRP Composites in Concrete Columns", Advances in Structural Engineering, 7(4), pp. 335-343, 2004. https://doi.org/10.1260/1369433041653552

[6] Kawashima, K., Shoji, M., Sakakibara, Y. "A Cyclic Loading Test for Clarifying the Plastic Hinge Length of Reinforced Concrete Piers", Journal of Structural Engineering A, 46A(2), pp. 767-776, 2000. (in Japanese) confined concrete strength up to $55 \%$. Similarly, the effect of increase of elastic modulus of FRPs on confined concrete strength is significant. But the effect of increase of diameter of concrete was opposite i.e. at lower values of diameter, the value of confined concrete strength was higher.

5. The confinement of steel-tubed columns using FRP material effectively prevents the outward local buckling and improves the structural performance in terms of axial loading capacity and axial deflection of columns. After the yielding of confining steel tube material, the impact of confinement is increased due to the incorporation of FRP material showing the column as an efficient structural member.

6. The proposed capacity equation based on the regression analysis for predicting the ultimate axial loading capacity of STFC composite columns presented a close agreement with the predictions of FEA model with a coefficient of determination of $0.93 \%$. Thus, the proposed capacity equation can be used for the analysis and design of STFC columns accurately.

\section{Conflict of interest}

Authors declare that they have no conflicts of interest.

[7] Takemura, H., Kawashima, K. "Effect of loading hysteresis on ductility capacity of reinforced concrete bridge piers", Journal of Structural Engineering, 43A, pp. 849-58, 1997.

[8] Hoshikuma, J., Kawashima, K., Nagaya, K., Taylor, A. W. "StressStrain Model for Confined Reinforced Concrete in Bridge Piers", Journal of Structural Engineering, 123(5), pp. 624-633, 1997.

[9] Sheikh, S. A., Toklucu, M. T. "Reinforced Concrete Columns Confined by Circular Spirals and Hoops", ACI Structural Journal, 90(5), pp. 542-553, 1993. https://doi.org/10.14359/3949

[10] Salawu, O. S., Williams, C. "Review of full-scale dynamic testing of bridge structures", Engineering Structures, 17(2), pp. 113-121, 1995. https://doi.org/10.1016/0141-0296(95)92642-1

[11] Cheok, G. S., Stone, W. C. "Behavior of 1/6-Scale Model Bridge Columns Subjected to Inelastic Cyclic Loading", ACI Structural Journal, 87(6), pp. 630-638, 1990. https://doi.org/10.14359/2943

[12] Li, G., Kidane, S., Pang, S.-S., Helms, J. E., Stubblefield, M. A. "Investigation into FRP repaired RC columns", Composite Structures, 62(1), pp. 83-89, 2003. https://doi.org/10.1016/s0263-8223(03)00094-1

[13] Delgado, P., Arêde, A., Vila Pouca, N., Rocha, P., Costa, A., Delgado, R. "Retrofit of RC hollow piers with CFRP sheets", Composite Structures, 94(4), pp. 1280-1287, 2012. https://doi.org/10.1016/j.compstruct.2011.11.032 
[14. Del Rey Castillo, E., Griffith, M., Ingham, J. "Seismic behavior of RC columns flexurally strengthened with FRP sheets and FRP anchors", Composite Structures, 203, pp. 382-395, 2018.

https://doi.org/10.1016/j.compstruct.2018.07.029

[15] Giakoumelis, G., Lam, D. "Axial capacity of circular concrete-filled tube columns", Journal of Constructional Steel Research, 60(7), pp. 1049-1068, 2004. https://doi.org/10.1016/j.jcsr.2003.10.001

[16] Lam, D., Gardner, L. "Structural design of stainless-steel concrete filled columns", Journal of Constructional Steel Research, 64(11), pp. 1275-1282, 2008.

https://doi.org/10.1016/j.jcsr.2008.04.012

[17] Liew, J. Y. R., Xiong, D. X. "Effect of preload on the axial capacity of concrete-filled composite columns", Journal of Constructional Steel Research, 65(3), pp. 709-722, 2009. https://doi.org/10.1016/j.jcsr.2008.03.023

[18] Han, L.-H., Li, W., Bjorhovde, R. "Developments and advanced applications of concrete-filled steel tubular (CFST) structures: Members", Journal of Constructional Steel Research, 100, pp. 211228, 2014.

https://doi.org/10.1016/j.jcsr.2014.04.016

[19] Tam, V. W. Y., Wang, Z.-B., Tao, Z. "Behaviour of recycled aggregate concrete filled stainless steel stub columns", Materials Structures, 47, pp. 293-310, 2014. https://doi.org/10.1617/s11527-013-0061-1

[20. Perea, T., Leon, R. T., Hajjar, J. F., Denavit, M. D. "Full-Scale Tests of Slender Concrete-Filled Tubes: Interaction Behavior", Journal of Structural Engineering, 140(9), Article number: 04014054, 2014. https://doi.org/10.1061/(asce)st.1943-541x.0000949

[21] Ding, F., Liu, J., Liu, X., Yu, Z., Li, D. "Mechanical behavior of circular and square concrete filled steel tube stub columns under local compression", Thin-Walled Structures, 94, pp. 155-166, 2015. https://doi.org/10.1016/j.tws.2015.04.020

[22] Liu, J.-P., Xu, T.-X., Wang, Y.-H., Guo, Y. "Axial behaviour of circular steel tubed concrete stub columns confined by CFRP materials", Construction and Building Materials, 168, pp. 221-231, 2018. https://doi.org/10.1016/j.conbuildmat.2018.02.131

[23] Sharif, A. M., Al-Mekhlafi, G. M., Al-Osta, M. A. "Structural performance of CFRP-strengthened concrete-filled stainless steel tubular short columns", Engineering Structures, 183, pp. 94-109, 2019. https://doi.org/10.1016/j.engstruct.2019.01.011

[24] Cevik, A., Cabalar, A. F. "A genetic-programming-based formulation for the strength enhancement of fiber-reinforced-polymerconfined concrete cylinders", Journal of Applied Polymer Science, 110(5), pp. 3087-3095, 2008. https://doi.org/10.1002/app.28839

[25] Cevik, A., Guzelbey, I. H. "Neural network modeling of strength enhancement for CFRP confined concrete cylinders", Building and Environment, 43(5), pp. 751-763, 2008. https://doi.org/10.1016/j.buildenv.2007.01.036

[26] Cevik, A., Göğüş, M. T., Güzelbey, İ. H., Filiz, H. "Soft computing based formulation for strength enhancement of CFRP confined concrete cylinders", Advances in Engineering Software, 41(4), pp. 527-536, 2010.

https://doi.org/10.1016/j.advengsoft.2009.10.015
[27] Naderpour, H., Kheyroddin, A., Amiri, G. G. "Prediction of FRPconfined compressive strength of concrete using artificial neural networks", Composite Structures, 92(12), pp. 2817-2829, 2010. https://doi.org/10.1016/j.compstruct.2010.04.008

[28] Ahmad, A., Khan, Q., Raza, A. "Reliability Analysis of Strength Models for CFRP-Confined Concrete Cylinders", Composite Structures, 244, Article number: 112312, 2020. https://doi.org/10.1016/j.compstruct.2020.112312

[29] Cevik, A. "Modeling strength enhancement of FRP confined concrete cylinders using soft computing", Expert Systems with Applications, 38(5), pp. 5662-5673, 2011. https://doi.org/10.1016/j.eswa.2010.10.069

[30] Oreta, A. W. C., Ongpeng, J. M. C. "Modeling the confined compressive strength of hybrid circular concrete columns using neural networks", Computers and Concrete, 8(5), pp. 597-616, 2011. https://doi.org/10.12989/cac.2011.8.5.597

[31] Elsanadedy, H. M., Al-Salloum, Y. A., Abbas, H., Alsayed, S. H. "Prediction of strength parameters of FRP-confined concrete", Composites Part B: Engineering, 43(2), pp. 228-239, 2012. https://doi.org/10.1016/j.compositesb.2011.08.043

[32] Jalal, M., Ramezanianpour, A. A. "Strength enhancement modeling of concrete cylinders confined with CFRP composites using artificial neural networks", Composites Part B: Engineering, 43(8), pp. 2990-3000, 2012. https://doi.org/10.1016/j.compositesb.2012.05.044

[33] Mashrei, M. A., Seracino, R., Rahman, M. S. "Application of artificial neural networks to predict the bond strength of FRP-to-concrete joints", Construction and Building Materials, 40, pp. 812-821, 2013. https://doi.org/10.1016/j.conbuildmat.2012.11.109

[34] Pham, T. M., Hadi, M. N. S. "Predicting Stress and Strain of FRPConfined Square/Rectangular Columns Using Artificial Neural Networks", Journal of Composites for Construction, 18(6), Article number: 04014019, 2014. https://doi.org/10.1061/(asce)cc.1943-5614.0000477

[35] Fardis, M.N., Khalili, H.H. "FRP-encased concrete as a structural material", Magazine of Concrete Research, 34(121), pp. 191-202, 1982. https://doi.org/10.1680/macr.1982.34.121.191

[36] Richart, F. E., Brandtzæg, A., Brown, R. L. "Failure of plain and spirally reinforced concrete in compression", University of Illinois at Urbana Champaign, Champaign, IL, USA, Rep. 190, 1929.

[37] Newman, K., Newman, J. B. "Failure theories and design criteria for plain concrete", In: Te'eni, M. (ed.) Structure, Solid Mechanics and Engineering Design, Wiley, London, UK, 1971, pp. 963-995.

[38] Mander, J. B., Priestley, M. J. N., Park, R. "Theoretical Stress-Strain Model for Confined Concrete", Journal of Structural Engineering, 114(8), pp. 1804-1826, 1988. https://doi.org/10.1061/(asce)0733-9445(1988)114:8(1804)

[39] Lam, L., Teng, J. G. "Design-oriented stress-strain model for FRPconfined concrete", Construction and Building Materials, 17(6-7), pp. 471-489, 2003. https://doi.org/10.1016/s0950-0618(03)00045-X

[40] Pessiki, S., Harries, K. A., Kestner, J., Sause, R., Ricles, J. M. "Axial Behavior of Reinforced Concrete Columns Confined with FRP Jackets", Journal of Composites for Construction, 5(4), pp. 237-245, 2001. 
[41] Chen, J. F., Li, S. Q., Bisby, L. A., Ai, J. "FRP rupture strains in the split-disk test", Composites Part B: Engineering, 42(4), pp. 962 972, 2011. https://doi.org/10.1016/j.compositesb.2010.12.015

[42] Tao, Z., Wang, Z.-B., Yu, Q. "Finite element modelling of concrete-filled steel stub columns under axial compression", Journal of Constructional Steel Research, 89, pp. 121-131, 2013 https://doi.org/10.1016/j.jcsr.2013.07.001

[43] Hassanein, M. F., Kharoob, O. F., Liang, Q. Q. "Behaviour of circular concrete-filled lean duplex stainless steel-carbon steel tubular short columns", Engineering Structures, 56, pp. 83-94, 2013. https://doi.org/10.1016/j.engstruct.2013.04.016

[44] Ellobody, E. "A consistent nonlinear approach for analysing steel, cold-formed steel, stainless steel and composite columns at ambient and fire conditions", Thin-Walled Structures, 68, pp. 1-17, 2013. https://doi.org/10.1016/j.tws.2013.02.016

[45] Liang, Q. Q., Fragomeni, S. "Nonlinear analysis of circular concrete-filled steel tubular short columns under axial loading", Journal of Constructional Steel Research, 65(12), pp. 2186-2196, 2009. https://doi.org/10.1016/j.jcsr.2009.06.015

[46] Hu, B., Wang, J., Li, G. "Numerical simulation and strength models of FRP-wrapped reinforced concrete columns under eccentric loading", Construction Building Materials, 25(5), pp. 2751-2763, 2011. https://doi.org/10.1016/j.conbuildmat.2010.12.036

[47] Mazzucco, G., Salomoni, V. A., Majorana, C. E., Pellegrino, C., Ceccato, C. "Numerical investigation of concrete columns with external FRP jackets subjected to axial loads", Construction and Building Materials, 111, p. 590-599, 2016. https://doi.org/10.1016/j.conbuildmat.2016.02.050

[48] Ribeiro, F., Sena-Cruz, J., Branco, F. G., Júlio, E. "3D finite element model for hybrid FRP-confined concrete in compression using modified CDPM", Engineering Structures, 190, pp. 459-479, 2019. https://doi.org/10.1016/j.engstruct.2019.04.027

[49] Wang, Z., Feng, P., Zhao, Y., Yu, T. "FRP-confined concrete core-encased rebar for RC columns: Concept and axial compressive behavior", Composite Structures, 222, Article number: 110915, 2019. https://doi.org/10.1016/j.compstruct.2019.110915

[50] Roudsari, S. S., Hamoush, S. A., Soleimani, S. M., Madandoust, R. "Evaluation of large-size reinforced concrete columns strengthened for axial load using fiber reinforced polymers", Engineering Structures, 178, pp. 680-693, 2019. https://doi.org/10.1016/j.engstruct.2018.09.071

[51] Shen, Q., Wang, J., Wang, J., Ding, Z. "Axial compressive performance of circular CFST columns partially wrapped by carbon FRP", Journal of Constructional Steel Research, 155, pp. 90-106, 2019. https://doi.org/10.1016/j.jcsr.2018.12.017

[52] Patel, V. I., Liang, Q. Q., Hadi, M. N. S. "Nonlinear analysis of axially loaded circular concrete-filled stainless steel tubular short columns", Journal of Constructional Steel Research, 101, pp. 9-18, 2014. https://doi.org/10.1016/j.jcsr.2014.04.036

[53] Tao, Z., Uy, B., Liao, F., Han, L. "Nonlinear analysis of concrete-filled square stainless steel stub columns under axial compression", Journal of Constructional Steel Research, 67(11), pp. 17191732, 2011. https://doi.org/10.1016/j.jcsr.2011.04.012
[54] Ellobody, E., Young, B., Lam, D. "Behaviour of normal and high strength concrete-filled compact steel tube circular stub columns", Journal of Constructional Steel Research, 62(7), pp. 706-715, 2006. https://doi.org/10.1016/j.jcsr.2005.11.002

[55] Teng, J. G., Jiang, T., Lam, L., Luo, Y. Z. "Refinement of a DesignOriented Stress-Strain Model for FRP-Confined Concrete", Journal of Composites for Construction, 13(4), pp. 269-278, 2009. https://doi.org/10.1061/(asce)cc.1943-5614.0000012

[56] Lim, J. C., Karakus, M., Ozbakkaloglu, T. "Evaluation of ultimate conditions of FRP-confined concrete columns using genetic programming", Computers \& Structures, 162, pp. 28-37, 2016. https://doi.org/10.1016/j.compstruc.2015.09.005

[57] Karbhari, V. M., Gao, Y. "Composite Jacketed Concrete Under Uniaxial Compression - Verification of Simple Design Equations", Journal of Materials in Civil Engineering, 9(4), pp. 185-193, 1997. https://doi.org/10.1061/(asce)0899-1561(1997)9:4(185)

[58] Saafi, M., Toutanji, H., Li, Z. "Behavior of Concrete Columns Confined with Fiber Reinforced Polymer Tubes", ACI Materials Journal, 96(4), pp. 500-509, 1999. https://oi.org/10.14359/652

[59] Matthys, S., Toutanji, H., Audenaert, K., Taerwe, L. "Axial Load Behavior of Large-Scale Columns Confined with Fiber-Reinforced Polymer Composites", ACI Structural Journal, 102(2), pp. 258-267, 2005.

https://doi.org/10.14359/14277

[60] Toutanji, H. "Stress-Strain Characteristics of Concrete Columns Externally Confined with Advanced Fiber Composite Sheets", ACI Materials Journal, 96(3), pp. 397-404, 1999.

https://doi.org/10.14359/639

[61] Samaan, M., Mirmiran, A., Shahawy, M. "Model of Concrete Confined by Fiber Composites", Journal of Structural Engineering, 124(9), pp. 1025-1031, 1998. https://doi.org/10.1061/(asce)0733-9445(1998)124:9(1025)

[62] Miyauchi, K., Nishibayashi, S., Inoue, S. "Estimation of strengthening effects with carbon fiber sheet for concrete column", In: Proceedings of the 3rd International Symposium on Non-Metallic (FRP) Reinforcement for Concrete Structures, Sapporo, Japan, 1997, pp. 217-224.

[63] American Concrete Institute "ACI 440.2R-08 Guide for the design and construction of externally bonded FRP systems for strengthening concrete structures", American Concrete Institute, Farmington Hills, MI, USA, 2002

[64] Sadeghian, P., Fam, A. "Improved design-oriented confinement models for FRP-wrapped concrete cylinders based on statistical analyses", Engineering Structures, 87, pp. 162-182, 2015. https://doi.org/10.1016/j.engstruct.2015.01.024

[65] Liu, J., Zhou, X. "Behavior and strength of tubed RC stub columns under axial compression", Journal of Constructional Steel Research, 66(1), pp. 28-36, 2010. https://doi.org/10.1016/j.jcsr.2009.08.006

[66] Zhao, O., Afshan, S., Gardner, L. "Structural response and continuous strength method design of slender stainless steel cross-sections", Engineering Structures, 140, pp. 14-25, 2017. https://doi.org/10.1016/j.engstruct.2017.02.044 
[67] Buchanan, C., Gardner, L., Liew, A. "The continuous strength method for the design of circular hollow sections", Journal of Constructional Steel Research, 118, pp. 207-16, 2016. https://doi.org/10.1016/j.jcsr.2015.11.006

[68] Chang, X., Ru, Z. L., Zhou, W., Zhang, Y.-B. "Study on concretefilled stainless steel-carbon steel tubular (CFSCT) stub columns under compression", Thin-Walled Structures, 63, pp. 125-133, 2013. https://doi.org/10.1016/j.tws.2012.10.002

[69] Wu, J. Y., Li, J., Faria, R. "An energy release rate-based plastic-damage model for concrete", International Journal of Solids Structures, 43(3-4), pp. 583-612, 2006.

https://doi.org/10.1016/j.ijsolstr.2005.05.038

[70] Voyiadjis, G. Z., Taqieddin, Z. N. "Elastic Plastic and Damage Model for Concrete Materials: Part I-Theoretical Formulation", The International Journal of Structural Changes in Solids - Mechanics and Applications, 1(1), pp. 31-59, 2009.

[71] Lee, J., Fenves, G. L. "A plastic-damage concrete model for earthquake analysis of dams", Earthquake Engineering Structural Dynamics, 27(9), pp. 937-956, 1998.

https://doi.org/10.1002/(sici)1096-9845(199809)27:9<937::aideqe764>3.0.co;2-5
[72] Raza, A., Khan, Q., Ahmad, A. "Numerical Investigation of LoadCarrying Capacity of GFRP-Reinforced Rectangular Concrete Members Using CDP Model in ABAQUS", Advances in Civil Engineering, 2019, Article ID: 1745341, 2019. https://doi.org/10.1155/2019/1745341

[73] Raza, A., Khan, Q. "Experimental and numerical behavior of hybrid-fiber-reinforced concrete compression members under concentric loading", SN Applied Sciences, 2, Article number: 701, 2020.

https://doi.org/10.1007/s42452-020-2461-5

[74] Raza, A., Shah, S. A. R., Khan, A. R., Aslam, M. A., Khan, T. A., Arshad, K., Hussan, S., Sultan, A., Shahzadi, G., Waseem, M. "Sustainable FRP-Confined Symmetric Concrete Structures: An Application Experimental and Numerical Validation Process for Reference Data", Applied Sciences, 10(1), Article number: 333, 2020.

https://doi.org/10.3390/app10010333 